\title{
LEONARDO DE FIGUEROA, MAESTRO MAYOR DEL HOSPITAL DE LA CARIDAD DE SEVILLA
}

\section{LEONARDO DE FIGUEROA, MAIN MASTER OF THE HOSPITAL DE LA CARIDAD IN SEVILLE}

\author{
Teodoro Falcón Márquez \\ Universidad de Sevilla. España \\ tfm@us.es
}

Todos los indicios permiten precisar que Leonardo de Figueroa fue maestro mayor de esta institución desde 1676, cuando se inició un programa unitario bajo la supervisión de Miguel Mañara con el fin de concluir la iglesia, edificar las enfermerías, patio y escaleras, así como la fachada y otras dependencias. Todo ello se llevó a cabo entre 1676 y 1682. Entre otras cuestiones facilitamos datos sobre los orígenes de esta hermandad y las primeras fases constructivas del templo. También proponemos que Valdés Leal fue quien diseñó las yeserías y el autor de unas tablas petitorias.

Palabras clave: Hospital de la Caridad; Sevilla; Leonardo de Figueroa; Miguel Mañara; Valdés Leal.

All signs indicate that Figueroa was main master of this institution since 1676, when a unified program under the supervision of Miguel Mañara began in order to complete the church building, the infirmaries, the courtyard, the stairs, the façade and other dependencies. All this took place between 1676 and 1682. Among other questions we provide data on the origins of this brotherhood and the temple's early construction phases. We also propose that Valdés Leal was the one who designed the plasterwork.

Keywords: Hospital de la Caridad; Seville; Leonardo de Figueroa; Miguel Mañara; Valdés Leal.

\section{EL ESTADO DE LA CUESTIÓN}

Leonardo de Figueroa (1654-1730) es, sin duda, el arquitecto más importante del Barroco sevillano o, lo que es lo mismo, de Andalucía Occidental, al mismo tiempo que fue el creador y definidor de una escuela, en la que se formaron sus hijos Matías y Ambrosio, siendo el último eslabón su nieto Antonio. Integrador de 
la tradición y la modernidad supo fusionar, a través de un oficio aprendido desde abajo del escalafón, elementos ancestrales de la arquitectura local, tales como el uso del ladrillo, la cerámica, la decoración de yeserías y las cubiertas de tejas árabes, con nuevas formas procedentes de Italia, a base de curvas y contracurvas, elementos decorativos, así como efectos de perspectiva, que conoció a través de una formación libresca, tomada principalmente de los arquitectos y tratadistas: fray Lorenzo de San Nicolás, Borromini, Guarino Guarini, Andrea Pozzo y Wendel Dietterlin entre otros ${ }^{1}$. Como hemos manifestado en otra ocasión, el salto cualitativo de pasar de oficial de albañil a maestro mayor, culto y erudito, se produjo durante los años que estuvo trabajando en el hospital de la Caridad, en donde tuvo contacto con los artistas más prestigiosos del momento, profesores de la Academia de la Lonja, tales como Murillo, Valdés Leal, Pedro Roldán y Bernardo Simón de Pineda, entre otros ${ }^{2}$.

La reciente bibliografía sobre este arquitecto ha puesto de manifiesto nuevas aportaciones y rectificaciones sobre su obra. Entre las primeras hay que destacar su intervención en la capilla mayor de la iglesia sevillana de San Vicente, en la que restauró las cubiertas e hizo la decoración mural entre 1691 y 1693 bajo las

${ }^{1}$ De la amplia bibliografía sobre este arquitecto surgida a lo largo del siglo XX y comienzos del XXI, destacaremos SANCHO CORBACHO, Antonio: Arquitectura barroca sevillana del siglo XVIII. Madrid, 1952; ANGULO ÍÑIGUEZ, Diego: "Dos esculturas genovesas de 1682 en el Hospital de la Caridad de Sevilla. El arquitecto Leonardo de Figueroa", Archivo Español de Arte, 196, 1976; ANGULO ÍÑIGUEZ, Diego: "La Casa de los Venerables Sacerdotes", Boletín de Bellas Artes, 4, 1976; FALCÓN MÁRQUEZ, Teodoro: El Palacio de San Telmo. Sevilla, 1991; FALCÓN MÁRQUEZ, Teodoro: "Leonardo de Figueroa", en Artistas andaluces y artifices del arte andaluz. T. XXXV. La Coruña, 2001; FALCÓN MÁRQUEZ, Teodoro: "Leonardo de Figueroa artífice de la torre del Hospital de la Caridad", Laboratorio de Arte, 16, 2003; FALCÓN MÁRQUEZ, Teodoro: "Influencia de los grabados de Dietterlin en la arquitectura barroca sevillana", Laboratorio de Arte, 21, 2009; FALCÓN MÁRQUEZ, Teodoro: "La portada principal del Palacio de San Telmo de Sevilla: nuevas aportaciones e interpretaciones", en Diálogos de Arte. Granada, 2014, pp. 277-290; MORALES MARTÍNEZ, Alfredo J.: "Leonardo de Figueroa y el barroco polícromo en Sevilla", en Figuras e imágenes del Barroco. Estudios sobre el Barroco español y sobre la obra de Alonso Cano. Madrid, 1999, pp. 193-209; HERRERA GARCÍA, Francisco Javier: Noticias de Arquitectura (1700-1720). Sevilla, 1990; HERRERA, Francisco Javier y QUILES, Fernando: "Nuevos datos sobre la vida y la obra de Leonardo de Figueroa”, Archivo Español de Arte, 259-269, 1992; RIVAS CARMONA, Jesús: Leonardo de Figueroa. Una nueva visión de un viejo maestro. Sevilla, 1994; HIGUERA MELÉNDEZ, José Manuel: "Leonardo de Figueroa. Inicios y actividad pericial. Una obra y un testamento inéditos", Anuario de Historia de la Iglesia Andaluza, VI, 2013; e HIGUERA MELÉNDEZ, José Manuel: "Leonardo de Figueroa: Orígenes, aprendizaje y comienzos del maestro barroco sevillano", Academia, 2014, pp. 114-115.

${ }^{2}$ FALCÓN MÁRQUEZ, T.: “Leonardo de Figueroa”, op. cit., pp. 207-210. 
bóvedas góticas ${ }^{3}$. Por otra parte hay que descartar su intervención en la fachada de la iglesia de San Jorge, del hospital de la Caridad, de la que se le atribuían las trazas de la buhardilla de su remate. Ahora sabemos que la fachada y cubiertas del coro alto fueron renovadas por Francisco Martín, maestro mayor del hospital de la Caridad, arquitecto que conjuntamente con Figueroa había diseñado la torre de ese templo en 1721. Las obras que aludimos se ejecutaron en 1733, tres años después del fallecimiento de Leonardo ${ }^{4}$. Martín se inspiró para la buhardilla en modelos de Leonardo, particularmente en el de la fachada de la iglesia del Salvador.

\section{ANTECEDENTES: EL ARQUITECTO JUAN GONZÁLEZ}

Este edificio, con su iglesia dedicada a San Jorge, es uno de los espacios más sorprendentes del barroco sevillano. El programa ideológico del templo, diseñado por Miguel Mañara, se describe a través de esculturas de retablos, pinturas murales y en lienzo, además de yeserías, a través de los cuales se desarrolla la idea de que para que el cristiano alcance la vida eterna debe practicar obras de caridad y de misericordia ${ }^{5}$. Los orígenes de esta institución se hallan en una hermandad y cofradía de la Santa Caridad de Cristo, que estaba ubicaba desde finales del siglo

${ }^{3}$ HIGUERA MELÉNDEZ, J. M.: "Leonardo de Figueroa. Inicios y actividad pericial...", op. cit., pp. 15-17.

${ }^{4}$ RAMOS SUÁREZ, M. A.: "La fachada de la iglesia de San Jorge del Hospital de la Caridad de Sevilla", en Estudios sobre Miguel Mañara. Su figura y su época, santidad, historia y arte. Sevilla, 2011, pp. 493-550.

${ }^{5}$ La bibliografía sobre esta institución es ya densa, habiéndose abordado desde diversos puntos de vista: asistencial, sobre la vida y obra de Mañara, en el terreno histórico-artístico, así como sobre el programa ideológico de la decoración del templo. En el marco artístico destacaremos GESTOSO, José: Sevilla Monumental y Artística. T. III. Sevilla, 1892; LÓPEZ MARTÍNEZ, Celestino: "La Hermandad de la Santa Caridad y el Venerable Mañara", Archivo Hispalense, 2, 1943; VALDIVIESO, Enrique y SERRERA, Juan Miguel: El Hospital de la Caridad de Sevilla. Sevilla, 1980; BROWN, Jonathan: "Jeroglíficos de muerte y salvación. La decoración de la iglesia de la Hermandad de la Caridad en Sevilla”, en Imágenes e ideas en la pintura española del siglo XVII. Madrid, 1988, pp. 179-207; MORALES, Alfredo J.: "La fachada de la iglesia de la Caridad, según un dibujo de 1654", Arte sevillano, 3, 1983; AA.VV.: Retablo mayor de la Santa Caridad de Sevilla. Madrid, 2007; AA.VV.: Miguel Mañara. Espiritualidad y arte en el barroco sevillano (1627-1679). Sevilla, 2010; AA.VV.: Estudios sobre Miguel Mañara. Sevilla, 2011; y FERNÁNDEZ ROJAS, Matilde: Las Atarazanas de Sevilla. Sevilla, 2013. A esta bibliografía habrá que añadir las citadas al principio: ANGULO ÍÑIGUEZ, D.: "Dos esculturas genovesas de 1682...", op. cit.; FALCÓN MÁRQUEZ, T.: "Leonardo de Figueroa artífice de la torre...", op. cit.; RAMOS SUÁREZ, M. A.: "La fachada de la iglesia de San Jorge...", op. cit.; e HIGUERA MELÉNDEZ, J. M.: "Leonardo de Figueroa: Orígenes, aprendizaje y comienzos...", op. cit. 
$\mathrm{XV}$ junto a la iglesia de San Isidoro. Se trataba de una hermandad "de disciplina", que salía procesionalmente el Jueves Santo. En uno de sus pasos procesionaba el Santo Crucifijo, una cruz desnuda que hoy preside la escalera principal del hospital (Figura 1). Le acompañaba en otro paso la Virgen de la Caridad, una pequeña imagen que mide $0,89 \mathrm{~m}$, que data del último cuarto del siglo $\mathrm{XV}$, de procedencia flamenca ${ }^{6}$. Se restauró y policromó entre 1670-1673, cuando Bernardo Simón de Pineda hizo su retablo actual, en el lado del evangelio. La hermandad experimentó un notable incremento a mediados del siglo XVI, como se refleja en cabildo de 19 de agosto de 1565 en el que consta que fueron admitidos 120 nuevos miembros ${ }^{7}$. Este dato es importante porque ante ese aumento, sus miembros no cabían en la capilla, por lo que se planteó su traslado el 23 de julio de 1588 a otra en las Atarazanas, a extramuros de la ciudad, bajo la advocación de San Jorge 8 .

Esta modesta capilla, de una nave y muy baja de cota y de altura, resultó años después también pequeña, a lo que hay que sumar los estragos de las frecuentes inundaciones del río. Por esa razón se planteó ampliarla en varios cabildos $^{9}$. En 18 de marzo de 1645, Pedro Sánchez Falconete presentó ante escribano

${ }^{6}$ RODA PEÑA, José: "Virgen de la Caridad, Anónimo de los Países Bajos", en Miguel Mañara, espiritualidad y arte..., op. cit., p. 210.

7 Archivo de la Hermandad de la Caridad, Sevilla (A.H.C.S.), Libro donde se asientan las entradas de hermanos en esta cofradía de la sancta caridad de Nuestro Señor Jesucristo. Comiença el 19 de agosto. 1565 años. Ver GRANERO, Jesús M.: Don Miguel Mañara Leca y Colona y Vicentelo. Sevilla, 1961, p. 293.

8 A.H.C.S., Libro de acuerdos de cabildos de 1588 a 1771. Como datos curiosos recopilamos algunos acuerdos de 1588. Cabildo de 21 de febrero: "Que se hagan pasos de Pasión, como otros años se suele hacer" (f. 1r). Cabildo de 28 de febrero: "Que los días que fuesen serenos y claros, se saquen los pasos a la esquina de la iglesia de San Isidoro, de manera que las personas que estuvieren dentro de la capilla, oyendo el sermón, los puedan ver" (f. 1v.). Mismo día: "Que en la procesión de disciplina del Jueves Santo ningún cofrade vaya con vara, sino todos con túnica. Se acuerda que no se entregue la vela (cirios azules) a ningún cofrade que no lleve la túnica" (f. 2r). El itinerario fue el siguiente: "Iglesia mayor, la del Salvador, la de la Magdalena y San Pablo y la de San Isidoro" (f. 4r). Cabildo 23 de julio: "Se trató del traslado de la capilla, junto a la de San Isidoro, a la de San Jorge. La primera de las capillas pertenecía a la Hermandad, por renta de por vida de 36.100 maravedíes y 32 pares de gallinas, pero por estar todo el día la capilla cerrada, no tenía la Hermandad dinero, ya que no había cofrades que acudiesen a pedir limosnas, hasta el punto de que se debían dos tercios. Se acordó dejar esta capilla y trasladarse a la de San Jorge, en las Atarazanas, extramuros de la ciudad" (ff. 7v-9r).

${ }^{9}$ En un informe presentado por los diputados de la hermandad, fechado en 29 de abril de 1641, se indica "que dicha capilla está tan honda, que se baja a ella del suelo hollado de la dicha Resolana por diez escalones, de suerte que luego que se sale el río de su madre se inunda por los cimientos, con que no se puede en mucho tiempo decir las misas, ni acudir a las demás obras de caridad, con la grande humedad que queda en la dicha capilla... que es muy pequeña, por lo que hay que predicar fuera de ella... Pedimos y 
un pliego de condiciones en el que se describe el proyecto, que en líneas generales responde al actualmente ejecutado, con pequeñas modificaciones ${ }^{10}$. En el documento se especifica que la nueva iglesia se construya a "carne y cuero", en el solar de la antigua; que el suelo se eleve hasta 2 varas $(1,67 \mathrm{~m})$ sobre el de la calle; que delante de la puerta se haga una lonja o atrio con sus gradas; a espaldas del presbiterio se construya la sacristía; sobre el testero que mira al río se construya una torre -espadaña-, en donde debían voltear tres campanas, y que las bóvedas del templo fueran de medio círculo - cañón- con cuatro lunetos en cada parte, enlucidas con labor de yesería y molduras, "al uso moderno". De la vida y obra de Sánchez Falconete (1586/87-1666), quien llegó a ser maestro mayor de la catedral, del arzobispado y de la Lonja, existen varias publicaciones ${ }^{11}$. En la escritura citada se especifica que la ejecución de las obras las llevaría a cabo Juan González, del que no se sabía con certeza su cometido. Ahora mostramos cómo estuvo al frente de la construcción de esta iglesia hasta su fallecimiento, y que realizó algunas modificaciones sobre el proyecto inicial. Juan González (1606-1667) es un arquitecto hasta ahora poco valorado, pese a haber ostentado el cargo de maestro mayor y superintendente de la catedral (1664-1667). Concluyó las obras de la iglesia del Sagrario (1662), tras la jubilación de Sánchez Falconete, y fue el artífice de la reconstrucción de la iglesia de Santa María la Blanca (1662-1665), bajo los auspicios del canónigo Justino de $\mathrm{Neve}^{12}$. Las obras de la iglesia que analizamos comenzaron el 6 de febrero de 1645, día de Santa Dorotea. El arquitecto percibía 50 reales diarios, más diversos extras ${ }^{13}$.

suplicamos se sirva darnos licencia para que en el sitio que llaman del Alcaydía, propia de los Reales Alcáçares, se pueda alçar y ensanchar la dicha capilla, tomando el sitio de la dicha Alcaydía de ancho quatro varas, de más que hoy tiene la dicha capilla y para lo largo, ocho varas y asimismo quitando y deshaciendo unos aposentos que la dicha casa del Alcaydía tiene sobre la dicha capilla..." Biblioteca Capitular Sevilla, Fondos de Gestoso, XI, $\mathrm{n}^{\circ}$ 9, ff. 98-101.

${ }^{10}$ LÓPEZ MARTÍNEZ, Celestino: "La Hermandad de la Caridad y el venerable Mañara", Archivo Hispalense, 2, 1943, pp. 6-7.

${ }^{11}$ CRUZ ISIDORO, Fernando: El arquitecto sevillano Pedro Sánchez Falconete. Sevi1la, 1991; CRUZ ISIDORO, Fernando: Arquitectura sevillana del siglo XVII. Maestros mayores de la catedral y del Concejo Hispalense. Sevilla, 1997; y CRUZ ISIDORO, Fernando: "Don Miguel Mañara, impulsor de la construcción de la iglesia y hospital de la Caridad", en Miguel Mañara. Espiritualidad y arte en el barroco sevillano (1627-1679). Sevilla, 2010, pp. 51-59.

${ }^{12}$ FALCÓN, Teodoro: La capilla del Sagrario de la catedral de Sevilla. Sevilla, 1977, p. 165; FALCÓN, Teodoro: La iglesia de Santa María la Blanca. Sevilla, 2015, pp. 79-82; y ARENILLAS, Juan Antonio: Del clasicismo al barroco. Arquitectura sevillana del siglo XVII. Sevilla, 2005, pp. 205-207.

13 A.H.C.S., Libro antiguo (Libro por el que se hace cargo desde el 5 de febrero de 1645 ... para la obra que se hace en la capilla de la dicha Hermandad). En él figuran todas las 
Su construcción se inició por los pies, por lo que lo último que se edificó fue la capilla mayor y la sacristía, situada detrás del presbiterio. Se conoce un dibujo de la fachada, fechada en 1654, que se conserva en el Archivo General de Simancas $^{14}$. Forma parte de un expediente incoado el 19 de mayo de 1653, con una carta del Ayuntamiento de esta ciudad, dirigida al rey Felipe IV, por la que apoyan las peticiones de la hermandad de la Caridad, con el fin de que se le exonerase del tributo anual que pagaba a los Reales Alcázares de 500 reales: "por un pedazo se sitio que se les dio para labrar la iglesia que actualmente se está fabricando". Se adjunta un documento fechado el 13 de enero de 1654, en donde "presenta modelo de la fábrica que tiene hecha de la iglesia, de limosnas, y de lo poco que le falta para acabarla". En el dibujo se especifica: "Hasta aquí está hecha la obra". Estaba construida la fachada, a falta de la espadaña. Su fisonomía es muy diferente a la actual, ya que se transformó en 1733. De abajo arriba figuran en el diseño, en los intercolumnios, las imágenes de San Pedro y San Pablo. En el segundo cuerpo, a uno y otro lado del balcón, ostentan los blasones del rey gobernante, Felipe IV, y de Bernardo de Valdés, patrono perpetuo de la capilla mayor, quien falleció al año siguiente. En su testamento, suscrito en 14 de mayo de 1655, dejó a esta institución una cuantiosa cantidad para la construcción de la capilla mayor. En el segundo nivel figuran las imágenes de las virtudes teologales: Fe, Esperanza y Caridad. La espadaña prevista, según el dibujo, presenta dos cuerpos. El inferior, con alternancia serliana, alberga tres campanas, más otra en el ático. Recordemos que en el pliego de condiciones de Sánchez Falconete se especifica que habrían de colocarse tres campanas, y este proyecto es de cuatro. Para su decoración estaban previstas pilastras, inspiradas en láminas de Dietterlin ${ }^{15}$. En la memoria se indica también que se colocarían en las bóvedas "cuatro lunetos en cada parte", cuando son tres en los respectivos tramos. Todo ello nos permite aseverar que González hizo modificaciones sobre el plan que tenía previsto su maestro.

partidas de gastos de arena, ladrillos y jornales: "Item por 1.000 rs. que pagó a Juan González, albañil a quenta de la obra, los quales le dan adelantados como consta de la escritura que ha otorgado, que pasó ante Thomás de Palomares en un día del mes de março".

${ }_{14}$ MORALES, A. J.: "La fachada de la iglesia de la Caridad...", op. cit., pp. 9-15.

15 Como hemos adelantado la fachada actual es el resultado de la renovación llevada a cabo en 1733 por el maestro mayor del hospital, Francisco Martín, con la colaboración del alfarero José García y el pintor Francisco Ignacio Pérez de Pineda. Las figuras de San Pedro y San Pablo se sustituyeron por las de San Hermenegildo y San Fernando, atribuidas a Pedro Duque Cornejo. En lugar de los blasones se colocaron azulejos con las figuras ecuestres de San Jorge y Santiago. RAMOS SUÁREZ, M. A.: "La fachada de la iglesia de San Jorge...”, op. cit., pp. 493-510. 


\section{LA DECISIVA INTERVENCIÓN DE MIGUEL MAÑARA}

En el curso de la construcción del templo ingresó en esta hermandad Miguel Mañara el 10 de diciembre de $1662^{16}$, siendo elegido hermano mayor el 27 de diciembre de 1663. Por entonces las obras estaban paralizadas por falta de medios. La iglesia se hallaba sin abovedar y sin solería. Bajo su tutela prosiguieron de forma intermitente, al recibirse varios donativos. Entre 1664-1665 se soló el templo y el pórtico, bajo la dirección de González ${ }^{17}$. Aunque López Martínez manifiesta que Mañara invitó en 1664 a colaborar en el cierre de las bóvedas a Pedro López del Valle, maestro mayor de la ciudad, no debe entenderse como una falta de confianza con González, que había modificado el modelo de bóvedas y, sobre todo, la del teórico crucero. Era frecuente entonces que se pidiera consulta a otros arquitectos en estos casos. Puede apreciarse la autoría de González en el hecho de que al fallecer en octubre de 1667, cuando se hallaba construido el cuerpo de la iglesia -desde el 12 de junio-, meses después, en cabildo de 12 de febrero de 1668 se acordó "que se tome el sitio de la capilla mayor en los 20 ducados de censo que S.M. mandó y que se haga la escritura necesaria para ello y luego que sea tiempo se haga los cimientos y comience la obra, según planta y disposición que dejó Juan González, maestro de albañil"18. Respecto a las obras de la capilla mayor y sacristía, que finalizaron en 1670, se ha manifestado que las ejecutó Andrés Pérez de Ifar, maestro mayor de la catedral. Lo cierto es que había sido cesado el 30 de agosto de 1669 por una grave enfermedad. Consta que la realización material se llevó a cabo por los maestros albañiles Domingo de Paredes y Marcos Lora ${ }^{19}$, tal vez bajo la supervisión de Francisco Moreno, maestro mayor de fábricas del arzobispado y de los hospitales.

Desde que Miguel Mañara fue designado hermano mayor, asumió la supervisión de las obras, el programa ideológico de su decoración y la contratación de los artistas más importantes que laboraban en Sevilla, poniendo en muchos casos el dinero de su peculio. Esta gran empresa se llevó a cabo entre enero de 1664, hasta su fallecimiento el martes 9 de mayo de 1679. Desde el punto de vista arquitectónico, en este período se terminó el cuerpo de la iglesia (junio de 1667) y

16 A.H.C.S., Libro nuevo de Hermanos de la Hermandad de la Santa Caridad de Sevilla, f. 76.

17 A.H.C.S., Libro de autos que dio principio en el mes de enero del año 1619, Cabildos de 18-5-1664 y de 12-4-1665, ff. 51 y 507. En cabildo de 18 de mayo de 1664 consta la siguiente partida: "A Blas Muñoz (de Moncada), nuestro hermano, maestro escultor, que hizo la imagen del Señor San Jorge, se le dieron 400 rs. más de lo que se concertó, 1600 rs. Ibidem, ff. 448-449. Se trata del mismo escultor que realizó la imagen de San Joaquín, en un retablo de la nave de la epístola en la iglesia de Santa Ana. En cabildo de 13 de diciembre de 1665 (f. 536) se alude a un nuevo contrato con Juan González.

18 A.H.C.S., Libro de Cabildos que se inicia en 1619, f. 710.

19 GRANERO, J. M.: Don Miguel Mañara..., op. cit., p. 161. 
la construcción de la capilla mayor y sacristía (mayo de 1670) ${ }^{20}$. Ello permitió que a partir de ese momento se iniciara el programa decorativo a base de pinturas murales, yeserías, colocación de retablos y esculturas, pinturas en lienzo, además del mobiliario litúrgico. Lo que llegó a ver Mañara, con anterioridad a su fallecimiento en 1679, es lo siguiente: las yeserías del cuerpo de la iglesia, algunas de las cuales enmarcan lienzos de Murillo. Consta en cabildo de 12 de julio de 1670 que entonces se hallaban colocados los seis lienzos de las Postrimerías, realizados por Bartolomé Esteban ${ }^{21}$. En cabildo de 28 de diciembre de 1672 se alude a los pagos a Murillo por los lienzos y molduras de San Juan de Dios y de Santa Isabel de Hungría ${ }^{22}$.

Tenemos que recordar que en las condiciones establecidas en 1654 por Sánchez Falconete para la construcción de este templo, dice que: "se compromete a enlucirlas (las paredes y bóvedas) y enriquecerlas con labores de yeserías y molduras al uso moderno". Hasta entonces las había empleado Juan de Oviedo en una bóveda esquifada en la planta alta de la Casa de Pilatos (1603), en la escalera del antiguo convento de la Merced (hoy Museo de Bellas Artes, h. 1612); en la iglesia de Santa Clara, en colaboración con Miguel de Zumárraga (16201622). Asimismo se emplearon, entre otros edificios: en la iglesia de San Buenaventura (1626-1627), cuya labor se debe a las trazas de Francisco Herrera el Viejo y la ejecución material de Juan Bernardo de Velasco y Juan de Segarra. Las yeserías que decoran la iglesia de San Jorge no están documentadas. Sus trazas se han atribuido a Sánchez Falconete y su ejecución a los hermanos Borja ${ }^{23}$. Debieron realizarse entre 1669 y el 12 de julio de 1670. Estoy convencido que sus trazas se deben a Valdés Leal, quien se titula maestro arquitecto, pintor y escultor (Figura 2), por tanto el mismo artífice que las pinturas murales. Juan Valdés participó en el proceso decorativo de este templo desde que ingresó en esta hermandad en 1667, hasta su fallecimiento en 1690. Como escultor realizó los grupos escultóricos de la Virgen del Rosario para la capilla sacramental de la iglesia de San Andrés y para la sala de la Virgen de este hospital de la Caridad (1680). Asimismo, como escultor y decorador intervino en varias capillas y templos sevillanos, tales como la capilla de la Concepción (catedral), la citada capilla sacramental de San Andrés, la iglesia del Hospital de los Venerables y la de San Clemente, entre otras. Debemos insistir en el paralelismo existente entre los fondos arquitectónicos que

${ }^{20}$ En cabildo de 28 de diciembre de 1670 consta que se pagaron 1.500 reales por el aguamanil de la sacristía. A.H.C.S., Libro de autos que se inicia en 1619, f. 975.

${ }^{21}$ Brown estima que debieron ser encargados en 1667, cuando se concluyó el cuerpo de la iglesia. BROWN, J.: "Jeroglíficos de muerte y salvación...", op. cit., p. 188.

${ }_{22}$ A.H.C.S., Libro de Cabildos que comienza en 10 de enero de 1672 y acaba en 28 de diciembre de 1677, ff. 156 y 157.

${ }^{23}$ MORALES MARTÍNEZ, A.: La piel de la arquitectura. Yeserías sevillanas de los siglos XVII y XVIII. Sevilla, 2010, pp. 157-161. 
figuran en sus lienzos, con los de las pinturas murales y las yeserías. Por citar solo unos ejemplos recordemos los fondos con decoración de yeserías que figuran en Los Desposorios de la Virgen (catedral de Sevilla, 1657), los de la capilla sacramental de San Andrés (1668-1670), los que ejecutará con posterioridad en Jesús entre los doctores de la ley (Museo del Prado, 1686) y en la sacristía de la iglesia del hospital de los Venerables (1687). Los temas decorativos de las yeserías de este templo, que recuerdan a las de la iglesia de Santa María la Blanca (1665), están integrados por altorrelieves de ángeles niños y figuras monstruosas, frutos -entre ellos granadas-, ménsulas, motivos auriculares, "ces" contrapuestas, macollas, roleos, "cortezas", florones y orlas. Muchos de estos motivos están inspirados en láminas del tratado de Wendel Dietterlin ${ }^{24}$. En la bóveda del sotocoro figura además el blasón de la hermandad de la Caridad.

Sobre el retablo mayor se propuso su realización en cabildo de 12 de julio de 1670. De los dos proyectos presentados, el de Francisco Dionisio de Ribas y el de Bernardo Simón de Pineda, se eligió el de este último, quien recomendó en el contrato de 19 de julio que la parte escultórica la ejecutase Pedro Roldán. Valdés Leal, que lo suscribió como fiador, participó en las labores pictóricas ${ }^{25}$. En cabildo de 18 de enero de 1671 consta: "12.000 rs. de plata para la obra de la capilla mayor de la cual está hecho cargo el Sr. Don Miguel”26. La parte arquitectónica se hallaba finalizada en abril de 1673 y la policromía en $1675^{27}$. Con anterioridad, Valdés Leal había ejecutado los Jeroglíficos de las Postrimerías, entre 1671-1672, a raíz de la publicación de Mañara del Discurso de la verdad (1671). En cabildo de 28 de diciembre de 1672 consta: "Item costó el campanario y la campana principal que se puso en él 32.365 rs.vn." ${ }^{28}$. En el mismo cabildo se indica "que se pusieron

${ }^{24}$ FALCÓN, Teodoro: "Valdés Leal y la arquitectura sevillana", Laboratorio de Arte, 4, 1991, pp. 149-168; FALCÓN, T.: "Influencias de los grabados de Dietterlin...", op. cit., pp. 117-134: KINKEAD, Duncan T.: Pintores y doradores en Sevilla (1650-1699). Indiana, 2006, pp. 527- 572; y MARÍN FIDALGO, Ana María: La iglesia parroquial de la iglesia de San Andrés de Sevilla. Sevilla, 2003, pp. 131-141.

${ }^{25}$ Resulta curioso que al suscribir el contrato los artistas especifican lo siguiente: "E nos Bernardo Simón de Pineda, Juan de Valdés y Pedro Roldán... declaramos que no somos artilleros, monederos, ni labradores". LÓPEZ MARTÍNEZ, Celestino: Retablos y esculturas de traza sevillana. Sevilla, 1928, pp. 90-102.

26 A.H.C.S., Libro de autos que comienza en 1619, f. 112.

27 A.H.C.S., Anno de 1673 y de 1675. Cartas de pago de veinte y dos mil y quinientos ducados de vellón de Bernardo Simón, artífice, que hiço en madera, el retablo de la Capilla Maior de esta Yglessia de la Santta Charidad; y de Juan de Baldés, artífice que lo pintó, doró y estoffó.

28 A.H.C.S., Libro de cabildos que comienza en 10 de marzo de 1672, f. 158. Con anterioridad al estreno de la iglesia se realizaron varias laudas sepulcrales en 1672: "Mande Vm. Sr. Antonio de Lemos, capitán y tesorero, dar a Francisco Rodríguez (Escalona), maestro de cantería, 200 rs. por cuenta de las losas de las bóvedas que está haciendo para 
dos arbotantes de ladrillo que se hicieron para resguardo de la capilla mayor, lo que ascendió a 1.332 rs.vn.”. La construcción del retablo mayor y la falta de cimentación de la capilla ocasionaron unas grietas, por lo que hubo que reforzar el muro del lado del evangelio con esos contrafuertes exteriores. Cuando se consagró el templo el 16 de julio de 1674, aún no se habían iniciado las pinturas murales -comenzaron en 1678-; el retablo mayor estaba en blanco y faltaban por realizar varios retablos. En 8 de diciembre de 1675 el cabildo acordó "que se haga un cancel para la puerta principal de esta iglesia para el resguardo del daño que en ella hace el polvo" 29 . El 16 de marzo del año siguiente se pagaron a Bernardo Simón de Pineda 900 reales por su ejecución, y Diego Muñoz percibió 305 reales por la vidriera del cancel.

En 1677 se inició un amplio expediente por parte de Miguel Mañara, que se titula "indigno Hermano Mayor" de la Caridad, en el que se solicitaba al arzobispo que la iglesia de San Jorge tuviera sagrario, así como poder administrar los sacramentos. Argumentaba que se hallaban acogidos en el hospital más de 60 pacientes, leprosos y con enfermedades incurables, a los que por no poder acudir a la iglesia del Sagrario, de la que dependían, fallecían muchos sin haber recibido los últimos sacramentos. Entre los numerosos documentos manuscritos, insertos en un libro, se halla la frecuente correspondencia entre Mañara y el prelado, así como los decretos de aceptación por parte de la Sacra Congregación del Concilio, por lo que se pudo poner el Santísimo en el sagrario del altar mayor al año siguiente (29 de diciembre de 1678). Debemos destacar las dilaciones por parte del arzobispo en contestar, y las dificultades que ofrecieron el deán y cabildo catedral, así como los párrocos de la iglesia del Sagrario, porque esa aprobación lesionaba sus intereses económicos. En esa diatriba se planteó además quién debía guardar las llaves del sagrario de esta iglesia. El enfrentamiento aún seguía en $1687^{30}$.

Respecto al resto del edificio, Mañara, que solicitó al cabildo del 17 de julio de 1677 residir en él, llegó a ver el inicio de la construcción de los patios, proceso que comenzó en 1678. Simultáneamente se edificó la escalera principal (1676-1679). La parte hospitalaria que en su etapa inicial no tenía camas, comenzó tal como ha llegado a nosotros entre 1672-1674, con la edificación de la sala de Cristo. La sala de la Virgen data de 1676-1677 y la de San Antonio se inició en 1678, un año antes del fallecimiento del insigne hermano mayor. Asimismo vio don Miguel el inicio de la construcción del granero, situado tras la iglesia, del que se había manifestado que no se llegó a construir. También se hallaba en gran medida construida la fachada, ya que entre 1676-1677 se pusieron las ventanas,

la iglesia de la Santa Caridad (rúbrica de Miguel Mañara). A.H.C.S., Datas, leg. 1 (de 1671 a 1681). Hoja suelta de 1672. "A Francisco Jordán (30 de agosto de 1672), en sentar la losa y abrir las letras del capitán Luis Fernández de Luna, 350 rs."

29 A.H.C.S., Libro de cabildos que comienza en 10 de enero de 1672, f. 714.

${ }^{30}$ Archivo Catedral de Sevilla (A.C.S.), sección IX, leg. 153, nº 6. 
balcones y guardapolvos. De todo ello nos ocupamos en el epígrafe siguiente. Asimismo debemos destacar que el maestro cantero de este edificio fue Francisco Rodríguez Escalona, quien curó presuntamente de una enfermedad tras la visita de Mañara en septiembre de $1668^{31}$, fue el artífice de las gradas de mármoles rojos y negros que permiten acceder a la capilla mayor, y las dos columnas que sustentan el coro. Hay que tener presente que por iniciativa de Mañara, el cabildo había aprobado en 1671 que en ningún altar "se puedan poner escudos de armas, ni otras insignias de vanidad" 32 . Por esa razón cuando los albaceas testamentarios de Bernardo Valdés, patrono de la capilla mayor, intentaron poner en ella su blasón, don Miguel les convenció para que en su lugar solo se colocaran unos relieves de la Pasión de Cristo $^{33}$. Por ello en el lado del evangelio hay una monumental orla laudatoria, realizada en jaspe rosado y piedra negra, con decoración dorada, que consta de dos cuerpos. El inferior, de forma apaisada y ovalada, con decoración de "ces" contrapuestas, alberga relieves alusivos a la Pasión de Cristo: la cruz desnuda, clavos y la columna de la flagelación, bajo la representación del sol y la luna. Se remata en otra orla más pequeña, de forma vertical, en cuyo texto pone:

\section{ARMA \\ FVDATORIS NOSTRI}

La orla debió ser trazada por Valdés Leal y ejecutada por Rodríguez Escalona, seguramente entre 1674-1675, coincidiendo con la fase final de la policromía del retablo mayor. Tiene como antecedente la trazada por Valdés Leal en 1664, y ejecutada por el cantero Juan Donaire, para la capilla de la Concepción Grande de la catedral ${ }^{34}$. Asimismo debe relacionarse con la existente en la fachada de la iglesia del antiguo convento de San Pablo -la Magdalena-, obra que dirigió Leonardo de Figueroa, en la que ostenta el blasón del arzobispo Palafox y Cardona (1685-1701).

Rodríguez Escalona realizó con posterioridad las columnas de las enfermerías, la escalera principal, las columnas y fuentes del patio (1678-1682), así como la escalera de acceso a la iglesia y la columnata de la fachada del aposento de Mañara. Don Miguel falleció el martes 9 de mayo de 1679, después de haber suscrito su testamento en 17 de marzo. Siguiendo su última voluntad, se enterró al

${ }^{31}$ GRANERO, J. M.: Don Miguel Mañara..., op. cit., p. 406, nota 15. Cabildo de 10 de noviembre de 1669 .

32 A.H.C.S., Libro de actas capitulares que se inicia en 1619, Cabildo de 12-7-1671, ff. 1092-1093.

${ }_{33}$ GRANERO, J. M.: Don Miguel Mañara..., op. cit., pp. 413-414.

${ }^{34}$ FALCÓN, Teodoro: "El arquitecto de retablos y escultor Martín Moreno y los primeros retablos con columnas salomónicas”, Boletín de Arte, 4, 2013, pp. 81-82. 
día siguiente a la entrada principal de la iglesia, bajo una lápida con el siguiente texto: "Aquí yacen los huesos y cenizas del peor hombre que ha habido en el mundo. Rueguen a Dios por él”. Sin embargo ese mandato no se cumplió. Días después en cabildo de 22 de mayo se trató del traslado "a sitio más decente el cuerpo del venerable señor don Miguel" ${ }^{35}$. Se depositó en la cripta bajo la capilla mayor el 9 de diciembre ${ }^{36}$. En la lauda sepulcral se le define como "Reparador de este templo, ampliándolo y adornándolo para mayor culto del Altísimo”.

\section{LA DIRECCIÓN DE LAS OBRAS POR LEONARDO DE FIGUEROA}

Tras las aportaciones documentales realizadas por Higuera Meléndez (2013 y 2014), resumiremos previamente los primeros años de la actividad profesional de Leonardo. Nacido en Utiel en enero de 1654, en 1672, cuando tenía 18 años, su padre lo dejó en Sevilla bajo la tutela del arquitecto José García para aprender el oficio de albañilería por espacio de "cuatro años o menos". Siguiendo la endogamia de la época, Leonardo tres años después se casó con Isabel Quintero, hermana de su maestro. Con García colaboró en ese período en la construcción de casas y en reparos en la iglesia de San Lorenzo, pasando paulatinamente de peón a oficial y a maestro albañil, oficio que ostenta por primera vez en 1676, en el arrendamiento de una casa en la plaza de San Lorenzo. Un hito importante en su vida profesional lo marca el hecho de que en 16 de diciembre de ese año en el bautizo de su hija María de la Rosa, en la citada iglesia parroquial, figura como padrino el capitán Juan Martínez del Castillo, consiliario de la Caridad. Fue sin duda quien lo introdujo como maestro albañil en las obras de esa institución. A pesar de que ya trabajara en la Caridad desde esa fecha, la primera noticia documental que teníamos hasta ahora data del 13 de marzo de 1679, cuando figura en el listado de cuentas de la hermandad. Ahora aportamos, aunque no se le cite explícitamente, que Leonardo era maestro mayor de esta institución, al menos desde 1678, un año antes de los que se afirmaba hasta ahora. En cabildo de 23 de octubre de ese año se acordó "que se vendan unas casas principales en la calle San Vicente". Acuérdase las vea el maestro mayor y se le da comisión para que

35 A.H.C.S., Libro de cabildos que comienza en 10 de enero de 1677 y acaba en 28 de diciembre de 1680, f. 1614.

36 Véase DE CÁRDENAS, P. Juan: Breve relación de la muerte, vida, y virtudes del venerable Cavallero D. Miguel Mañara Vicentelo de Leca, caballero del Orden de Calatrava, Hermano Mayor de la Sancta Caridad. Sevilla, 1679. De la publicación de este libro hay constancia en el Libro de cabildos que comienza en 10 de enero de 1677, f. 1931. Aunque desde su fallecimiento se inició el proceso de beatificación de Mañara, hasta el 6 de julio de 1985 el pontífice Juan Pablo II no le ha proclamado venerable. 
se ajuste ${ }^{37}$. Sospecho que estaba al frente de las obras desde 1676, año del bautizo citado, cuando con 22 años era ya un hombre de confianza de esta institución y, particularmente, de Mañara. A partir de entonces intervino en la iglesia en la parte final de su ornato, en la restauración de la capilla mayor, pero sobre todo le dio carácter unitario a la zona hospitalaria, patios, escalera principal, así como la fachada del edificio y los aposentos de don Miguel en el hospital en los últimos años de su vida. Todo ello se construyó fundamentalmente entre 1676 y 1682. Leonardo estuvo de maestro mayor de esta entidad hasta $1687^{38}$. Esta es, por tanto, su primera gran obra. Cuando regresó a Sevilla en 1690, después de su estancia en Carmona, fue nombrado maestro mayor del antiguo convento de San Pablo, del hospital de los Venerables, etc., iniciándose en esa década su época dorada. Cuando volvió a este edificio hospitalario para colaborar en la construcción de la torre en 1721, era un prestigioso arquitecto reconocido en toda Andalucía.

\section{SU INTERVENCIÓN EN LA IGLESIA DE SAN JORGE}

En ella surgieron de nuevo grietas en la capilla mayor en 1679, después de haberse puesto unos estribos en 1672. De esos daños se hace eco el cabildo de 10 de septiembre de ese año. Entonces Valdés Leal se hallaba realizando la decoración de las pinturas murales ${ }^{39}$. Cuatro días después fueron reconocidas por Francisco Moreno, maestro mayor del arzobispado; Juan Domínguez, maestro mayor del hospital de los Venerables; Esteban García, maestro mayor de la catedral, y Leonardo de Figueroa, en calidad de maestro mayor de este hospital. A raíz de ese reconocimiento Leonardo construyó dos nuevos contrafuertes exteriores, en el lado del evangelio. Son de fábrica de ladrillo y se rematan en una airosa voluta ${ }^{40}$ (Figura 3). Consta en cabildo de 9 de marzo de 1680 que se suspendieron entonces las obras, a causa de la pérdida del poder adquisitivo de la moneda y de la hambruna

37 A.H.C.S., Libro de cabildos que comienza en 10 de enero de 1677, f. 1437. Estas casas se hallaban junto a la portería del monasterio de mercedarias descalzas de la Asunción.

${ }^{38}$ En 1685 figura realizando tres informes de casas propiedad de la hermandad de la Caridad. Una se encontraba en la Resolana -actual Temprado-, otra en la plazuela de los Escoberos -San Gil-. HIGUERA MELÉNDEZ, J. M.: "Leonardo de Figueroa. Inicios y actividad pericial...", op. cit., p. 10. A.H.C.S., Borradores de actas de cabildo, desde 1680 a 1698, Data y Descargo de todos los gastos desde primero de enero de 1684 hasta fin de diciembre de 1685, 1685, f. 48: "A Leonardo de Figueroa. Primeramente parece haber dado por libranzas de nuestro Hermano Mayor dos partidas, una de 600 rs. y otra de 137, que son 737 rs. que valen 25.058 mrs. a Leonardo de Figueroa por el tiempo que trabajó en la obra de la casa ${ }^{\circ} 24$ de la calle de la Muela".

${ }^{39}$ KINKEAD, D. T.: Pintores y doradores en Sevilla..., op. cit., p. 548.

${ }^{40}$ FALCÓN, T.: "El arquitecto de retablos y escultor Martín Moreno...", op. cit., pp. 501-506; e HIGUERA MELÉNDEZ, J. M.: "Leonardo de Figueroa: Orígenes, aprendizaje y comienzos...", op. cit., p. 17. 
que hubo en esta ciudad, circunstancias que se aprovecharon para que "tomase enjugo el reparo de la iglesia"41. Estas obras finalizaron en agosto de $1681^{42}$. En el año anterior consta la colocación de "un hierro para la media naranja" ${ }^{43}$. Esas intervenciones coincidieron con el traslado de los restos de Mañara a la cripta existente bajo la capilla mayor, lo que tuvo lugar el 9 de diciembre de 1679. Esa labor fue llevada a cabo bajo la dirección de Leonardo y la supervisión de Pedro Corbet, almirante de la Armada y nuevo hermano mayor de la Caridad. Los restos de don Miguel se colocaron en el lado de la epístola, y los de Bernardo de Valdés, fallecido en 1655, patrono de la capilla mayor que había dado una importante suma para su construcción, se ubicaron en el lado del evangelio ${ }^{44}$.

Leonardo debió colaborar con Valdés Leal diseñando el montaje para la realización de las pinturas al temple, que se ejecutaron entre el 20 de septiembre de 1678 y el 17 de octubre de 1682. Se hicieron en la bóveda elíptica del teórico crucero, pechinas y ventanas. Representan a los evangelistas -pechinas-, ángeles pasionarios -bóveda- y en las ventanas: San Julián-San Martín y Santo Tomás de Villanueva-San Juan Limosnero. Aunque no es el cometido de este artículo detenernos en la participación de Juan Valdés en este hospital, haremos solo una observación. Conserva esta institución cinco tablas pintadas "para las obligaciones e indulgencias", que han figurado en la exposición Miguel Mañara. Espiritualidad $y$ arte en el barroco sevillano (1627-1679 $)^{45}$. Cada una de ellas alude a las dedicaciones que los hermanos y diputados tenían que desempeñar de forma mensual. La dedicada a los entierros muestra al Patriarca Tobías dando sepultura a un

${ }^{41}$ A.H.C.S., Libro de cabildos que comienza en 10 de enero de 1677, ff. 1927-1928: "Da cuenta nuestro Hermano Mayor haber suspendido la obra, por el grande accidente de la baja de la moneda... en razón para paralizar la obra algunos días para que en ellos tomase enjugo el reparo de la iglesia, antes de pasar adelante en él". Véase GODOY, Francisco: Católica consolatoria exortación, que a los que en su patria han padecido las calamidades, que de ocho años, a esta parte se han experimentado. Sevilla, 1684.

${ }^{42}$ A.H.C.S., Libro $5^{\circ}$ de cabildos, Cabildo 10-8-1681, ff. 33v-34v: "El Hermano mayor da cuenta de haber terminado el importante reparo que se ha hecho en la capilla mayor de nuestra iglesia y que por tanto se podrán celebrar las fiestas que por dicho motivo habían estado suspendidas".

${ }^{43}$ Ibidem, Siglo XVII (Memorial de hierro): "En 3 de octubre de 1680 se pagó por un hierro para la media naranja, que pesó 22 libras, 33 rs.".

${ }^{4}$ DE CÁRDENAS, P. Juan: Breve relación de la muerte, vida, y virtudes del venerable Cavallero D. Miguel Mañara..., op. cit., pp. 35 y ss.; e HIGUERA MELÉNDEZ, J. M.: "Leonardo de Figueroa: Orígenes, aprendizaje y comienzos...", op. cit., p. 16. Bernardo Valdés en su testamento suscrito en 7 de mayo de 1655 había expresado su voluntad de enterrarse, solo en la capilla mayor, cuando se construyera. Esa manda no se cumplió. Como se dilató su construcción, mientras tanto su cuerpo había sido depositado en la iglesia de San Alberto.

${ }^{45}$ Hospital de la Caridad de Sevilla, marzo-mayo de 2010. 
pobre. La dedicada a los enfermos y peregrinos representa a Abraham hospedando a un pobre y un peregrino. La tabla dedicada a los cabildos muestra el blasón de la Santa Caridad. Otra está dedicada a las pláticas recomendadas por Mañara cada mes. En ella se representa la Muerte, Juicio, Infierno y Gloria -Novísimos-. La última se ha empleado para pedir limosnas para las Ánimas del Purgatorio. Sobre su autoría, de antiguo se han venido atribuyendo a Murillo, pese a la escasa afinidad con su estética. Se han fechado en 1673, en base a que se aluden unas tablas en el inventario de 1674, en el que no se precisa su autor ${ }^{46}$. Al parecer se renovaron en 1683 por Valdés Leal, a quien debemos adscribirlas ${ }^{47}$. A pesar de las escasas dimensiones de estas pinturas, pueden apreciarse en ellas algunos rasgos característicos de Valdés, tales como su interés por los fondos arquitectónicos, el carácter "declamatorio" de sus personajes y el mismo prototipo de ángeles niños.

\section{LA TORRE}

Ya documentamos que la torre actual, situada en la cabecera, lado del evangelio, se construyó en 1721 a raíz de un acuerdo capitular de 12 de enero de ese año. Previamente Francisco Martín, maestro mayor de la Caridad, y Leonardo de Figueroa habían informado de la ruina que amenazaba el campanario anterior. Los maestros propusieron que se edificara en el lugar donde Leonardo había construido uno de los contrafuertes entre 1680-1681 para reforzar la capilla mayor. Ambos arquitectos presentaron planta y alzado. En un lienzo existente en el Ayuntamiento de Sevilla, de pintor anónimo y fechado en 1726, se aprecia el primer documento gráfico de la nueva torre. Su modelo, muy singular por sus caprichosos remates y decoración de azulejos, pudo tener como antecedente la torre de la iglesia de la O, construida por Pedro Romero en 1699, aunque con posterioridad se remodeló su chapitel en 1756 por Pedro de Silva, tras el terremoto del año anterior. Las obras de este campanario ascendieron a 19.015 reales de vellón y concluyeron en octubre de 1721. Entre los motivos iconográficos, que se advierten a distancia, destaca en la fachada de poniente la fecha de conclusión: "AÑO DE 1721", y entre el texto la imagen de la Caridad. A su izquierda San Jorge y a la derecha Santa Inés. Sobre el arco del campanario, el escudo de la hermandad y en el azulejo superior, la Inmaculada. Uno de los cuerpos superiores del

${ }^{46}$ VALDIVIESO, E. y SERRERA, J. M.: El Hospital de la Caridad..., op. cit., pp. 83-84; e ILLÁN MARTÍN, Magdalena: catálogo de la exposición Miguel Mañara. Sevilla, 2010, pp. 158-158.

47 A.H.C.S., Data y Descargo de las cuentas que se ajustan desde principio del día de 1682 hasta fin de 1683, Cabildo de 13-4-1683: "A Juan de Valdés 1.400 rs. vn. por la obra de estofar y dorar las tablas de las obligaciones e indulgencias y en el banco y marco del lienzo de Ntra. Sra. de la Encarnación". A.H.C.S., Libro de Cuentas y Visitas de la Hermandad, f. 208. KINKEAD, D. T.: Pintores y doradores en Sevilla..., op. cit., p. 560. 
chapitel está decorado con esculturas, que tal vez representan a los Padres de la Iglesia ${ }^{48}$. La campana procede de la torre anterior. Fue fundida en 1696 por Ildefonso Méndez ${ }^{49}$.

\section{EL HOSPICIO Y LAS ENFERMERÍAS}

Miguel Mañara tras ser designado hermano mayor de la Caridad en 27 de diciembre de 1663, además de proseguir la tarea de la construcción de la iglesia y de dotarle de un rico patrimonio artístico, también asumió la fundación de un hospicio. Su primer establecimiento había sido muy modesto, un simple albergue, sin camas, para dar cobijo a vagabundos sin techo. En cabildo de 10 de enero de 1665 se aprobó un nuevo Reglamento, por lo que tras ese prolegómeno y las inquietudes de Mañara, se consiguió la construcción paulatina de tres enfermerías cuyo costo ascendió a 118.406 ducados $^{50}$. La primera se denominó sala del Santo Cristo de la Caridad, que se edificó entre 1672-1674. No hay constancia de que hubiera maestro mayor en esa fecha -Leonardo de Figueroa estaba aún aprendiendo el oficio-. Solo consta que Juan Rodríguez era el oficial, por lo que pudo construirse bajo la supervisión de Esteban García, maestro mayor de la catedral y del arzobispado. Aunque las gestiones se habían iniciado en $1668^{51}$, fueron tomando cuerpo en junio de 1670, cuando se aprobó ampliar el recinto primitivo, incorporando un almacén propiedad del Alcázar ${ }^{52}$. Para ello se acordó aplicar inicialmente un legado de 6.000 ducados de plata, al que se sumaron otros ${ }^{53}$. Las obras comenzaron en diciembre de 1672, con el acopio de materiales, entre los que figuran 60.000 ladrillos y un envío inicial de cinco columnas ${ }^{54}$. En noviembre de 1673 estaban las obras muy avanzadas, por lo que se planteó recibir "asistentes de los pobres para el nuevo hospital que se está acabando de fabricar en esta santa casa" 55 y el jueves 14 de junio de 1674 se hizo el traslado de los pobres a la

${ }^{48}$ MÁRQUEZ, T.: "Leonardo de Figueroa artífice de la torre...", op. cit., pp. 501506.

${ }^{49}$ GESTOSO, J.: Sevilla Monumental y Artística. T. III, op. cit., p. 326.

${ }^{50}$ Para su proceso histórico véase: GRANERO, J. M.: Don Miguel Mañara..., op. cit., pp. 326-329.

51 A.H.C.S., Libro de cabildos que se inicia en 1619, Cabildo de 12-8-1668, f. 733.

${ }^{52}$ Ibidem, Cabildo de 8-6-1670, ff. 886-887: "Se propuso la necesidad que hay de ensanchar el Hospicio y las razones que hay para ello. Que se tome un almacén que tiene don Nicolás de Toledo, que es propiedad del Alcázar".

${ }_{53}$ Ibid., Libro de cabildos que comienza el 10 de enero de 1672, Cabildo de 14-8-1672, f. 95.

${ }^{54}$ Cabildo de 28-12-1672, f. 164.

${ }_{55}$ Cabildo de 12-11-1673, ff. 304-305. 
nueva sala, llevados en brazos y a la espalda ${ }^{56}$. Entonces tenía solo doce camas, por lo que ya se acordó ampliar las instalaciones ${ }^{57}$. Ocupa esta sala una de las galerías de las Atarazanas, por tanto de planta rectangular, dividida en dos naves por una hilera de 11 columnas de orden toscano, sobre pedestales y se rematan en un doble cimacio. Sobre ellos voltean arcos semicirculares y bóvedas de arista de fábrica de ladrillo, como todo el recinto. Los tramos son de planta cuadrada. En diciembre de 1674 se colocó un retablo de madera ${ }^{58}$, hoy desaparecido. En su lugar hay otro, cerámico, de comienzos del siglo XX. La imagen de Cristo que preside, de madera policromada, mide de alto $2,05 \mathrm{~m}$. Se atribuye con fundamento a Pedro Roldán. Representa a un Cristo muerto, de tres clavos, con sudario anudado en el lado derecho, dejando al descubierto el muslo. La cruz es cilíndrica. Debe ser el primero de la serie de crucificados que con posterioridad ejecutó. En abril de 1687 aparecieron una serie de fisuras en la sala, que dañaron a "la columna inmediata al altar, por lo que habiendo llamado a los mejores maestros de obras de Sevilla", habían coincidido en que la causa del daño era el vaciado de un arco que se cortó por medio ${ }^{59}$. El acceso a esta sala, como la de la Virgen es lateral, cegándose las arcadas de las Atarazanas. Ambas enfermerías se hallan cerradas en la actualidad. Solo se abren para exposiciones temporales.

La sala de la Virgen del Rosario (1678-1680) se edificó junto a la anterior, en la nave más próxima a la iglesia, bajo la dirección de Leonardo. Las limitaciones de espacio para acoger a nuevos enfermos había planteado la necesidad de construir una nueva sala ya en $1675^{60}$. Sin embargo, hasta diciembre de 1677 no se solicitaron al rey dos casas y unos almacenes para la nueva construcción ${ }^{61}$. Sus propietarios, doña María del Castillo y don Ignacio de Lemos, traspasaron a la hermandad sus derechos. Con esa ampliación se alcanzaría el número de $60 \mathrm{ca}$ $\operatorname{mas}^{62}$. Para la construcción de la nueva sala se aplicaron varios legados de hermanos, entre los que cabe destacar el del marqués de Paradas (500 ducados), el del capitán Alonso López (1.000 ducados) y el de Francisco Gómez de Castro

${ }^{56}$ Cabildo de 10-6-1674, f. 421. Idem., Datas, leg.1. 31-7-1674. "Memoria de los gastos hechos en el aderezo del Hospital Viejo, de blanquearlo y hacer la ventana y reja, puerta de ella y fortificar la bóveda y hechura del aposentillo". Se libraron 25 jornales a Juan Rodríguez, oficial a 12 reales, total 1.900 reales.

${ }^{57}$ GRANERO, J. M.: Don Miguel Mañara..., op. cit., p. 361.

${ }^{58}$ Cabildo de 28-12-1674. "Retablo del Cristo de la Caridad. Costó 18.700 rs. Idem. Costó el tabernáculo del Santo Cristo del altar del Hospicio, con el terciopelo, peana, etc.: 8.000 rs. vn."

${ }^{59}$ Cabildo de 13-4-1687, ff. 288v y 289r, y Cabildo de 8-6-1687, ff. 291v y 292r.

${ }^{60}$ Cabildo 23-3-1676, ff. 858-859: "Escritura para tener los sitios del Alcázar para agrandar este Hospital, según los acuerdos de 6 de abril de 1675 y 26 de febrero de 1676".

${ }^{61}$ A.H.C.S., Libro de cabildos que comienza en 10 de enero de 1677, Cabildo de 12-12-1677, f. 1156.

${ }^{62}$ Cabildo de 26-5-1678, ff. 1309-1313. 
$(16.000 \text { pesos })^{63}$. En 1678 el maestro cantero Francisco Rodríguez Escalona realizó las once columnas que dividen la sala, como la del Santo Cristo, cuya labor no se terminó de pagar hasta el año siguiente ${ }^{64}$ (Figura 4). El hecho de tener una columna menos que la anterior se debe a que se suprimió un tramo en la cabecera. Para darles mayor altura se peraltan con basamentos. Tienen también los soportes un doble cimacio, pero aquí el superior ofrece un perfil bulboso. En fotografías antiguas se aprecia cómo sobre el remate bulboso hay dos prismas más, decorados con pinjantes y cartelas. Las bóvedas, rebajadas, son asimismo de arista. Concluida la parte constructiva en 1680, en primero de ese año se hizo un pago a Diego Muñoz por la realización de las vidrieras ${ }^{65}$. Hoy muchos vanos están cegados. Entre 1679 y 1680 se realizó el retablo, “caja y altar” que preside la sala. Fue ejecutado por Bernardo Simón de Pineda, con la colaboración pictórica de Valdés Leal ${ }^{66}$. La talla de la imagen titular $(1,43 \mathrm{~m})$ la hizo Valdés Leal en $1680^{67}$. En agosto de 1683 el tesorero Mateo de Vitoria realizó un pago "de 36

${ }^{63}$ Cabildos de 8-11-1676, f. 951; de 17-10-1677, f. 1135; y de 13-11-1678, f. 1442. En el testamento de Gómez de Castro (28-4-1678) y en cabildo de 5-6-1679 consta que los 16.000 pesos se destinen a la enfermería nueva "que está en término de acabarse". En el desglose se especifica que para la construcción se apliquen 14.000 reales, 1.000 para la compra de 24 camas con su ropa y 1.000 para hacer el altar y la imagen de la Virgen. KINKEAD, D. T.: Pintores y doradores en Sevilla..., op. cit., p. 554.

${ }^{64}$ A.H.C.S., Siglo XVII, Papeles curiosos. 11-9-1678: "Las once columnas de la Enfermería le costaron a don Miguel ( $1^{\mathrm{a}}$ fase) $1.856 \mathrm{rs}$. vn. Borrador de las Cuentas que dio nuestro Hermano Antonio de Lemos, de tiempo que fue tesorero hasta fin de diciembre de 1679, que dejó de serlo. (obra de cantería). Item se reciben en data 3732 ducados que valen 126.888 mrs. A Francisco Rodríguez, maestro cantero por resto de ya juramentado de la cuenta que tenía de toda la obra que había hecho hasta fin del año pasado de 1679".

${ }_{65}$ A.H.C.S., Libro de Data que comienza en 1677, Tesorería 2. En 19 de junio de 1680 se libraron 18.725 reales a Diego Muñoz, maestro vidriero por las vidrieras y farolas para la enfermería nueva.

${ }^{66}$ Cabildo de 11-6-1679, f. 1636: "Tres mil pesos para el retablo de la Enfermería de Nuestra Señora y mil para el sagrario de plata". Cabildo de 10-9-1679, f. 1771: "Se libraron 1000 pesos para el retablo de la Enfermería de Ntra. Sra. del Rosario". Cabildo de 281-1680, f. 2070: "Item se han dado a Juan de Baldés y a Bernardo Simón 10.150 rs. a cuenta de un retablo que se ha hecho para la Enfermería de Ntra. Sra. y otras obras que se están haciendo para el culto divino". Libro de Data que comienza en 1677, Tesorería 2, f. 40v: "En 5 de agosto de 1680 a Bernardo Simón de Pineda 2000 rs.vn. de 500 ducados en que se ajustó el retablo de Ntra. Sra. del Rosario".

${ }^{67}$ KINKEAD, Duncan T.: Juan de Valdés Leal (1622-1690). Nueva York, 1978, pp. 613-614. VALDIVIESO, E. y SERRERA, J. M.: El Hospital de la Caridad..., op. cit., pp. 26-27. A.H.C.S., Data de la Tesorería de 1680 (Juan de Baldés): "En 3 de julio de 1680 se realizó un pago de 750 rs.vn. a Juan de Baldés, por quenta de la echura de Ntra. Sra. del Rosario que hace para la Enfermería". Ajustamiento de Baldés: "En 7 de octubre de 1682 dio 
pesos por la hechura de la corona de Ntra. Sra. del Rosario" ${ }^{98}$. Por otra parte hay constancia de un pago por dos columnas en 1690. Debe tratarse de las existentes delante de la puerta lateral de la sala de Cristo, que se abre hacia el pequeño patio llamado de los Montpensier, en recuerdo de su visita a esta institución en 18 de septiembre de $1862^{69}$.

Sala de San Antonio (1678-1682). En vista de la demanda de los enfermos, coincidiendo prácticamente con la construcción de la sala de la Virgen, se inició esta nueva enfermería. Se halla ubicada a la izquierda de la del Santo Cristo, pero más corta, a causa de la ubicación a sus pies de un pequeño patio y de la escalera de acceso a la iglesia por parte del personal. Se inició su construcción el 30 de septiembre de 1678, pero no se habilitó hasta el 18 de julio de 1682, tras la paralización general de las obras por la crisis económica. No tiene columnas en su interior y quedó cubierta como eran primitivamente estos almacenes, de cañón apuntado, en la que se abrieron claraboyas para la iluminación natural. En su testero preside una pequeña talla de San Antonio de Padua (1,05 m), de la primera mitad del siglo XVIII ${ }^{70}$. En la actualidad la sala está dedicada a comedor del asilo.

\section{LA FACHADA (1676-1677)}

Es monumental, de fábrica de ladrillo, apaisada y de dos plantas (Figura 5). Se abre hacia la calle Temprado y al antiguo Arenal. Muestra una sencilla composición a base de ventanas adinteladas con rejas en planta baja, y ventanas voladas en la alta con guardapolvos de pizarra. La puerta de ingreso se halla desplazada hacia la derecha, por lo que se distribuyen cinco ventanas a su izquierda y dos a la derecha. La portada se enmarca con pilastras toscanas, coronadas con ménsulas invertidas (Figura 6). Sobre ella se ubica el balcón principal, tras el que se encuentra la estancia destinada a archivo de la hermandad. Tiene antepecho de hierro forjado y guardapolvo de pizarra con tornapuntas. Su entablamento se decora a base de pares de dentellones, tema que se repitió en la remodelación del

libranza nuestro Hermano Mayor de 3.200 rs.vn. a Juan de Baldés con lo que se acaba de pagar 32.250 rs.vn. que importa toda la obra que ha hecho en la iglesia, casa y hospital".

68 A.H.C.S., Siglo XVII, Libramiento de 12-8-1683.

${ }^{69}$ A.H.C.S., leg. 1, Data de 1688 a 1691, Año de 1690, Libranzas y gastos mensuales: "En 23 de diciembre de 1690 se pagaron 400 rs. vn. que importaron dos columnas que se compraron para la obra".

70 VALDIVIESO, E. y SERRERA, J. M.: El Hospital de la Caridad..., op. cit., pp. 2728; y CRUZ ISIDORO, F.: "Don Miguel Mañara, impulsor de la construcción...”, op. cit., p. 57. Como la cita no es precisa desconozco si el dato siguiente corresponde a las cubiertas de esta sala. A.H.C.S., Data de 1688 a 1691. En 20 de diciembre de 1690, "se adquirieron 26 vigas para la obra". 
cuerpo superior de la fachada de la iglesia en 1733. Esta crujía se remata con una cubierta de tejas árabes a dos aguas. Se construyó principalmente entre los años de 1676-1677, sin duda bajo la dirección de Leonardo. El maestro herrero que ejecutó las rejas y balaustrada del balcón fue José de Almoguera, el mismo que realizó los balcones y balaustrada del patio y escalera principal. Los guardapolvos de pizarra son labor del cantero Rodríguez Escalona ${ }^{71}$. Con ocasión de la renovación del cuerpo superior de la fachada de la iglesia, "se hizo un reparo de toda la fachada de la casa y portada de la iglesia y ruina que amenazaba la armadura del coro alto y en todo el vuelo del tejado". La restauración se llevó a cabo bajo la dirección del entonces maestro mayor del hospital, Francisco Martín, entre el 2 de enero y el 17 de marzo de 1733. Su costo ascendió a 4.989 reales $^{72}$.

\section{EL PATIO PRINCIPAL (1678-1682)}

Se sitúa tras la crujía de fachada orientada hacia el Arenal, quedando desplazado hacia la izquierda con relación a la portada de acceso desde el exterior. Enlaza por un lado (este) con las dos primeras enfermerías; al norte con la antigua sala de cabildos y con la iglesia, y al sur, con la escalera principal. Es de planta rectangular. Mide 31,16 x 14,88 m, por tanto es de proporción dupla. Se organiza en base a dos módulos de planta cuadrada, con cinco columnas en cada frente, salvo en la parte oriental, donde se intesta en las enfermerías (Figura 7). No está justificada, desde la puerta de acceso la existencia de una galería central, desplazada a la izquierda, con doble hilera de columnas. No es correcta la afirmación de que el modelo deriva del siglo XVI, del hospital Tavera (Toledo), ya que en ese edificio renacentista la puerta está a eje con la iglesia, y los patios se sitúan simétricamente a uno y otro lado, tras la puerta de ingreso. Aquí esa estrecha galería conduce a las enfermerías a través de una pequeña puerta adintelada. Se cubre con un envigado de madera, como las demás. En el patio de la Virgen -o de la $\mathrm{Fe}$-, a la izquierda, se ubican el despacho del hermano mayor, la secretaría, la sala de cabildos, tránsito a la iglesia para la visita cultural y el acceso lateral a la sala de la Virgen. El patio del Santo Cristo -o de la Caridad-comunica con la puerta principal y las primitivas oficinas del P. Mayor y del P. Capellán Mayor. En alzado, en planta baja, los soportes son columnas de mármol grisáceo, de orden toscano, con doble cimacio, sobre las que voltean arcos semicirculares. Repite el mismo modelo que en las enfermerías. En el centro de cada espacio cuadrado presiden sendas fuentes con tallas de mármol blanco. Fue Angulo quien documentó por primera vez que en 1678 el maestro cantero Francisco Rodríguez Escalona fue el encargado de iniciar en esa fecha las columnas y las tazas de las

\footnotetext{
${ }^{71}$ A.H.C.S., Siglo XVII, Data del maestro herrero, 1676.

72 A.H.C.S., Libro de Tesorería de 1727 a 1734, Data para el año de 1733.
} 
fuentes. De las 22 columnas se hicieron en ese año quince ${ }^{73}$. Además se colocaron cuatro capiteles ménsulas intestados en los muros de las enfermerías. Las obras se fueron demorando por la crisis económica, de tal forma que la fase final se remató entre 1681-1682. La documentación es numerosa, por lo que extractamos algunos pagos ${ }^{74}$. Las fuentes son de mar octogonal. Presiden ellas las tallas de la $\mathrm{Fe}$-en el patio más próximo a la iglesia-y la de la Caridad -patio de Cristo, próximo a la entrada principal-. Según Angulo se trajeron de Génova en 1682, sin duda están realizadas en mármol de Carrara por un escultor anónimo. Esa fecha figura en ambos pedestales, al dorso de las tallas. Entre el pedestal y las tallas de mármol hay sendos basamentos en piedra, de inferior calidad, con relieves de carátulas fantásticas inspiradas en Dietterlin, por cuyas bocas se vierte el agua a la fuente. También fueron labradas por Rodríguez Escalona. Todo ello bajo la supervisión de Leonardo de Figueroa, como había sugerido Angulo.

La segunda planta del patio es cerrada, con cuatro balcones en cada frente, salvo en el inteste de las enfermerías, decorados con orejetas y flanqueados por pilastras toscanas enlazadas a través de una imposta. En las enjutas hay una decoración a base de triángulos, con dos lados curvos. Los balcones son de hierro forjado, lo mismo que las ventanas, algunas con tejaroces, que dan luces a las enfermerías ${ }^{75}$. Las cubiertas son de las tradicionales tejas morunas, que vierten el agua de la lluvia hacia el patio. Muy interesante es la espadaña, ubicada en la parte oriental, en medio de las dos primeras enfermerías (Figura 8). Es de un vano, para albergar una campana, y está flanqueada por pilastras con capitelesménsula. Este modelo tiene antecedentes en la decoración de yeserías de la iglesia del convento de Santa Clara (1620-1622), y en la nave central de la iglesia de Santa María la Blanca (1665). Leonardo lo adoptó, con o sin decoración, en esta espadaña (1682). A continuación figuran en la iglesia de los Venerables (1686), la capilla mayor de San Vicente (1691-93), la portada del crucero (1691) y la cúpula de la Magdalena (1694), la fachada de la iglesia de los Venerables (1699), el cuerpo de campanas de la torre del Salvador (1718-1719) y en San Telmo bajo las

${ }^{73}$ ANGULO ÍÑIGUEZ, D.: "Dos esculturas genovesas de 1682...”, op. cit., p. 453.

74 A.H.C.S., Libro de Data que se inicia en 1677, Tesorería 2, f. 40v: "En 28 de julio de 1681 se pagaron a Francisco Rodríguez Escalona por cuenta de la pila para el segundo patio, 1000 rs.". Ibidem, Data de 1682: "En 16 de enero de dicho año por libranza de nuestro Hermano Mayor se pagaron a favor de Francisco Rodríguez Escalona 500 rs. vn. por cuenta de la fuente que ha hecho para el sitio de la Enfermería de Ntra. Sra." Ibid., Data del Sr. Tesorero de los años 1682, 1683, 1684 y 1685: "En 11 de septiembre de 1682 por libranza de nuestro Hermano Mayor se pagaron a Francisco Rodríguez Escalona 500 rs.vn. por cuenta de los pedestales de las fuentes".

${ }^{75} \mathrm{El}$ maestro herrero que trabajó a las órdenes de Leonardo durante los años de 1676-1677 en el patio, escalera principal y fachada fue José de Almoguera. A.H.C.S., Siglo XVII, Papeles curiosos. 
torres del patio principal y en la fachada exterior de la capilla, ambas ultimadas por su hijo Matías (1730-1734).

\section{LA ESCALERA PRINCIPAL}

Se sitúa en el frente meridional del patio, a la derecha de la puerta de ingreso. Queda enmarcada por el arco central de este frente. Es de caja rectangular, de un tiro, con tres tramos en sentido levógiro -hacia la izquierda-, con pasamanos de hierro forjado y se cubre con una excepcional armadura de madera de limas moamares, de tres paños, de tradición mudéjar. En el testero preside el Santo Crucifijo que salía procesionalmente el Jueves Santo. Se trata del sector más inédito, desde el punto de vista documental, del edificio. La labor de cantería fue realizada entre 1676-1679 por Rodríguez Escalona, los herrajes por José de Almoguera y la carpintería por Lucas Arias, quien aparece también en varios informes de casas propiedad de la Caridad, junto con Figueroa ${ }^{76}$.

\section{OTRAS DEPENDENCIAS}

Graneros (1679-1680)

Otra de las tareas constructivas en esta institución fue la edificación de unos graneros. Higuera cita un acuerdo capitular de septiembre de 1679 en el que consta "que luego se labren unos Graneros en el sitio que corre desde el comedor de la sacristía nueva hasta llegar a el fin de el Hospiçio". Según este autor, las labores habrían sido encomendadas a Leonardo como maestro mayor: "Finalmente, dicha obra no se llevó a cabo" "77. Lo cierto es que se edificaron entre 1679 y

${ }^{76}$ A.H.C.S., Siglo XVII. Documentos curiosos. En 15 de diciembre de 1677 está fechada una declaración de gastos que el cantero Rodríguez Escalona realizó en este edificio, concretamente en la escalera principal y en los balcones. Su montante fue de 7.015 reales de vellón. También consta un pago al maestro herrero José de Almoguera en la misma fecha por 8 balcones del patio y dos rejas de la escalera que pesan 81 arrobas y 20 libras. Ibidem, leg. 1, Data de 1671 a 1681. En 1679 constan diversos pagos a Rodríguez Escalona por la escalera, en los que se especifican soleras, pasamanos, pedestales, balaustres, dos bolas jaspeadas y pilares del estribo, entre otros. Asimismo hay otros pagos complementarios en Borradores de las cuentas que dio nuestro hermano Antonio de Lemos en tiempos que fue tesorero hasta fin de 1679.

${ }^{77}$ HIGUERA MELÉNDEZ, J. M.: "Leonardo de Figueroa: Orígenes, aprendizaje y comienzos...", op. cit., p. 18. 
1680. Tenían como soportes pilares y se cubrían con una armadura de madera de pinos de Segura. En su lugar hay en la actualidad varios patios ${ }^{78}$.

\section{Escalera de acceso a la iglesia}

Se halla adosada al lado de la epístola del templo, en el pasillo de acceso lateral a la sala de la Virgen y a los aposentos de Mañara. Muy interesante es su frontis de alternancia serliana, que Leonardo de Figueroa repetirá en la fachada de la iglesia de San Luis (1699-1700), entre otros edificios (Figura 9). Los soportes son aquí de columnas pareadas de mármol de Carrara. La escalera se intesta en el muro de la derecha. Es de un tiro y se decora con azulejos blancos y azules. Se construyó entre 1679-1680 por el cantero Rodríguez Escalona, bajo la dirección de Leonardo ${ }^{79}$. Sobre los arcos hay sendos azulejos alusivos a que servía de tránsito a los hermanos al templo y a las dependencias de las hermanas de la Caridad, que prestaron servicio aquí durante más de cien años. Los textos son los siguientes:

\author{
TRÁNSITO \\ A LA IGLESIA \\ PARA LOS HERMANOS
}

\author{
DEPARTAMENTO \\ DE \\ HERMANAS
}

${ }^{78}$ A.H.C.S., Libro de cabildos que comienza en 10 de enero de 1677, Cabildo de 28-121679, f. 1874: "Item se han gastado este año en la obra que está haciendo esta hermandad así de la nueva Enfermería como de los Graneros y reparo de la iglesia: 315.000 rs." Ibidem, Libro de Data que se inicia en 1677, Tesorería 2, Cabildo de 31-12-1679, f. 40: "Graneros. 552 pesos de oro que di a Francisco Javier, mercader de madera, por el valor de 48 cargas de madera de Segura que dio para los Graneros que se están haciendo". Ibid., En Borrador de la cuenta que dio nuestro Hermano Antonio de Lemos de tiempo que fue tesorero hasta fin de diciembre de 1679, que dejó de serlo, Libro de Cabildos que comienza en 10 de enero de 1677, Cabildo de 9-3-1680, ff. 1927-1928: "Da cuenta nuestro Hermano Mayor había suspendido la obra, por el gran accidente de la baja de la moneda... para que tomase enjugo los cimientos y pilares de los Graneros el asiento conveniente antes de cargarles las maderas". Ibid., Cabildo 11-8-1680, f. 2010: "Que prosigan las obras, que había tomado el enjugo necesario".

79 A.H.C.S., Datas, leg. 1 (1671 a 1681), Quenta que dio Francisco Rodríguez, maestro cantero por el resto y ajustamiento de todas las obras que hizo en la Santa Caridad del año de 79. Memoria de las obras: " 1 o en la escalera que va a la iglesia hay 9 pasos en todo su largo, de la medida de la escalera principal, por lo cual se hizo el ajustado asiento a 70 rs. cada uno, que regulados los 9 pasos importan 1530 rs.". 


\section{Aposentos de Miguel Mañara}

El 17 de octubre de 1677, don Miguel solicitó al cabildo "una pobre celda para que logre, en el fin de mis días, la dicha de morir en ella". Con anterioridad el entonces hermano mayor había abandonado la casa-palacio familiar de la calle Levíes y había alquilado otra más modesta y más próxima al hospital ${ }^{80}$. Aunque el cabildo le ofreció que eligiera para vivir en "el cuarto, celda o aposento que quisiere", creo que lo que se hizo es construir un edificio prácticamente exento, más alto que profundo, de tres plantas, que se halla ubicado tras la cabecera de la iglesia (Figura 10). Su planta noble se organiza con cuatro arcos semicirculares sobre tres columnas dórico-toscanas. A su izquierda se sitúa la escalera que da acceso a la planta alta. Los aposentos se organizan en tres sencillas habitaciones, con solería de barro cocido, muros encalados y armaduras de madera. Su modesto balcón se enmarca entre columnas genovesas. La planta alta es adintelada sobre pilares, con decoración de pilastras toscanas. Esta edificación debió llevarla a cabo Leonardo entre 1677-1678, quien tuvo que contar con su equipo habitual: el cantero Rodríguez Escalona, el herrero José de Almoguera y el carpintero Lucas Arias. Poco tiempo residió aquí el hermano mayor. El 17 de marzo de 1679 suscribió su testamento, falleciendo el 9 de mayo, cuando tenía solo 52 años. Delante de estos aposentos se colocó en 1920 una columna con el busto de Mañara realizado en bronce por José Lafita y a sus pies los cuatro macetones de rosales, que según la tradición trajo don Miguel de su casa.

Fecha de recepción: 5 de septiembre de 2016

Fecha de aceptación: 4 de enero de 2017

${ }^{80}$ GRANERO, J. M.: Don Miguel Mañara..., op. cit., p. 392, nota 31. Según algunos autores esa vivienda más próxima se hallaba en la plaza de la Contratación. 


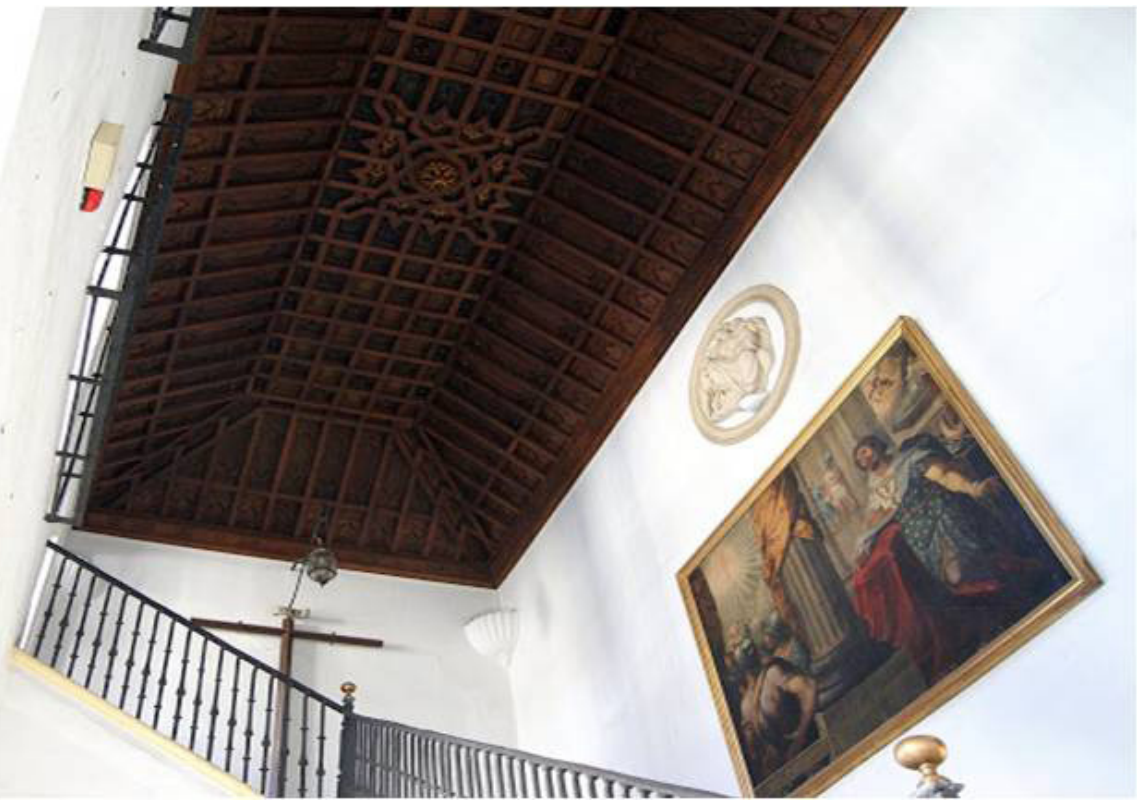

Figura 1. Escalera principal con el Santo Crucifijo.

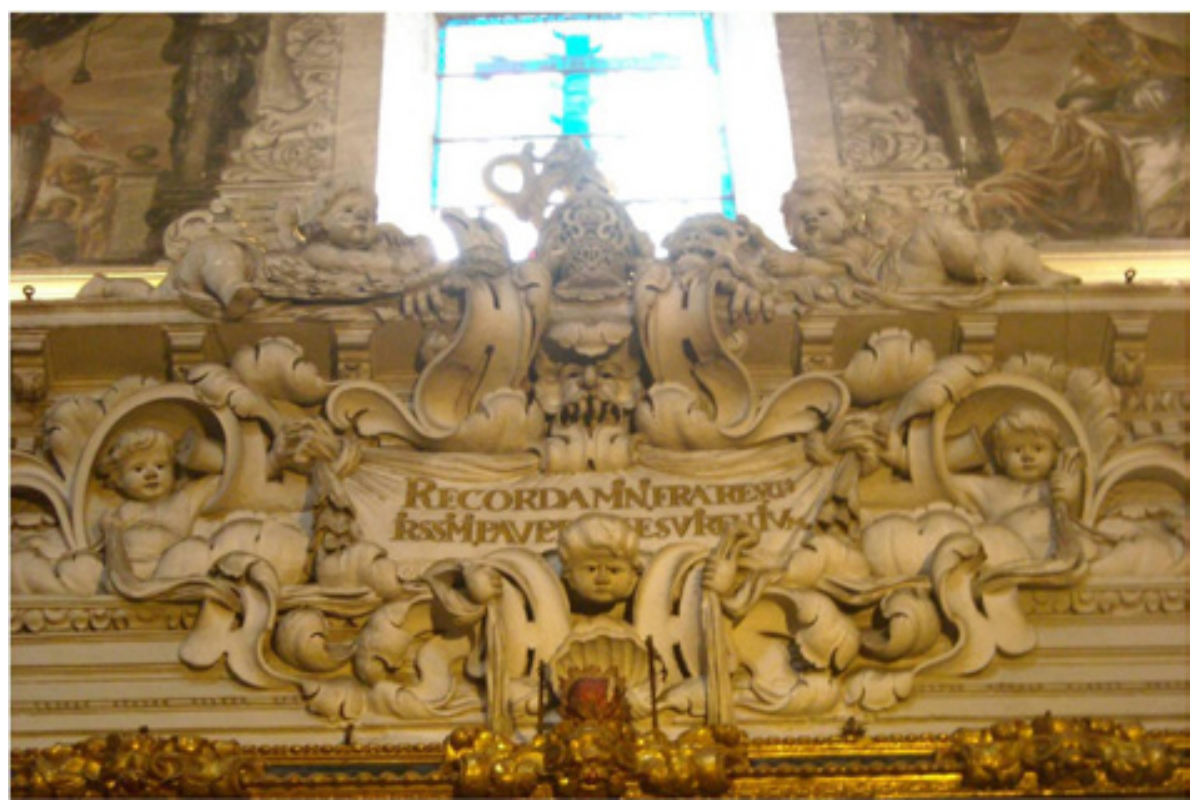

Figura 2. Yeserías probablemente trazadas por Valdés Leal.

LABORATORIO DE ARTE 29 (2017), pp. 329-358, ISSN 1130-5762 e-ISSN 2253-8305 - DOI http://dx.doi.org/10.12795/LA.2017.i29.18 


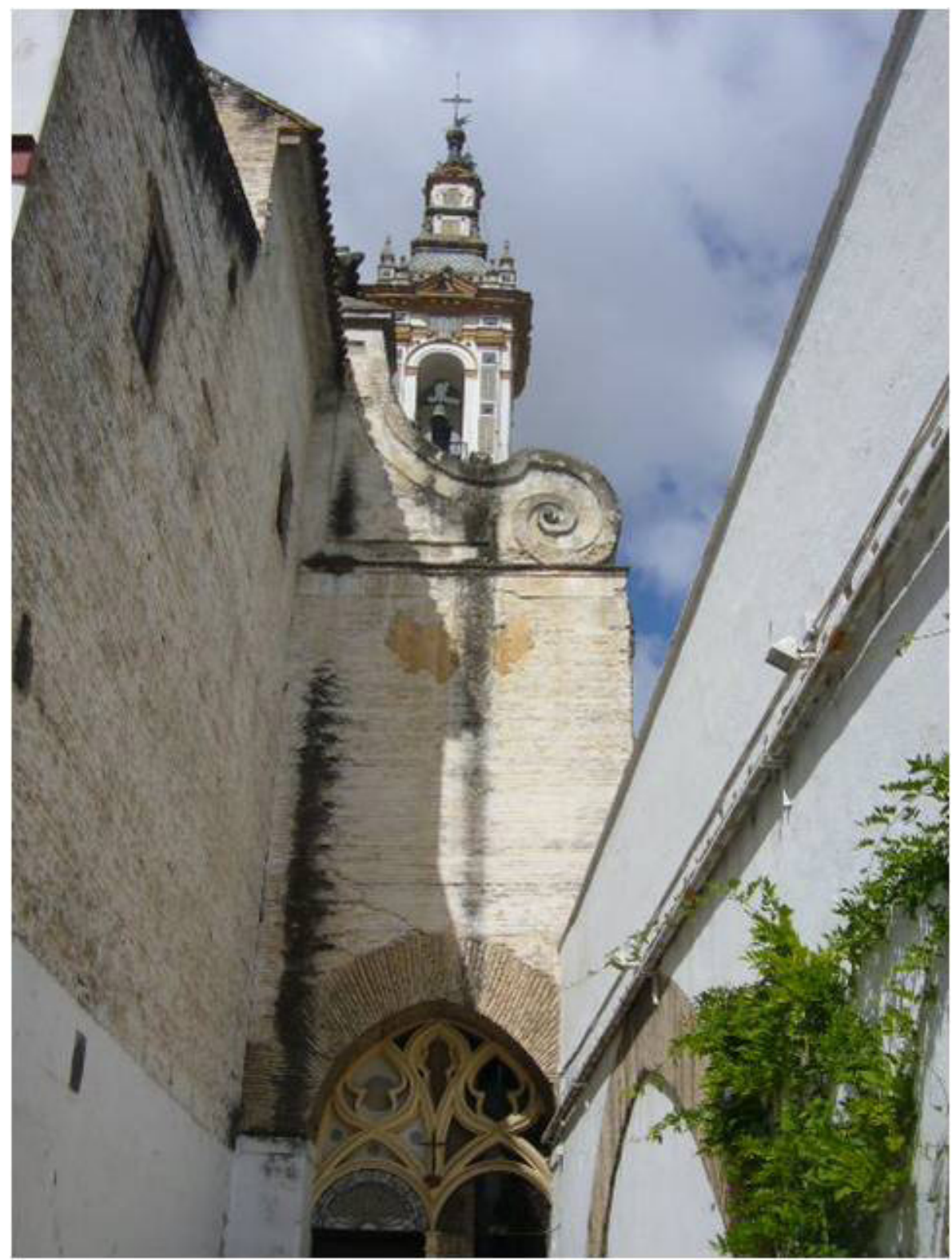

Figura 3. Contrafuerte y torre construidos por Leonardo de Figueroa. Arco neogótico de 1894. 


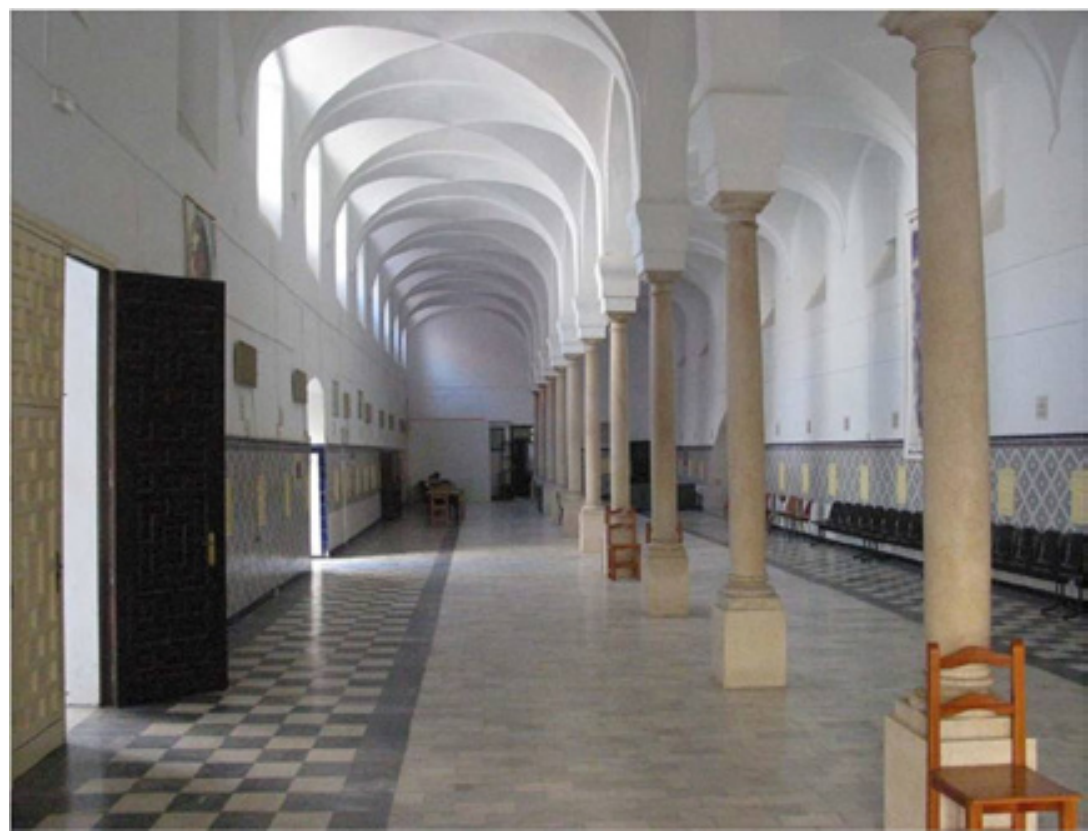

Figura 4. Sala de la Virgen del Rosario.

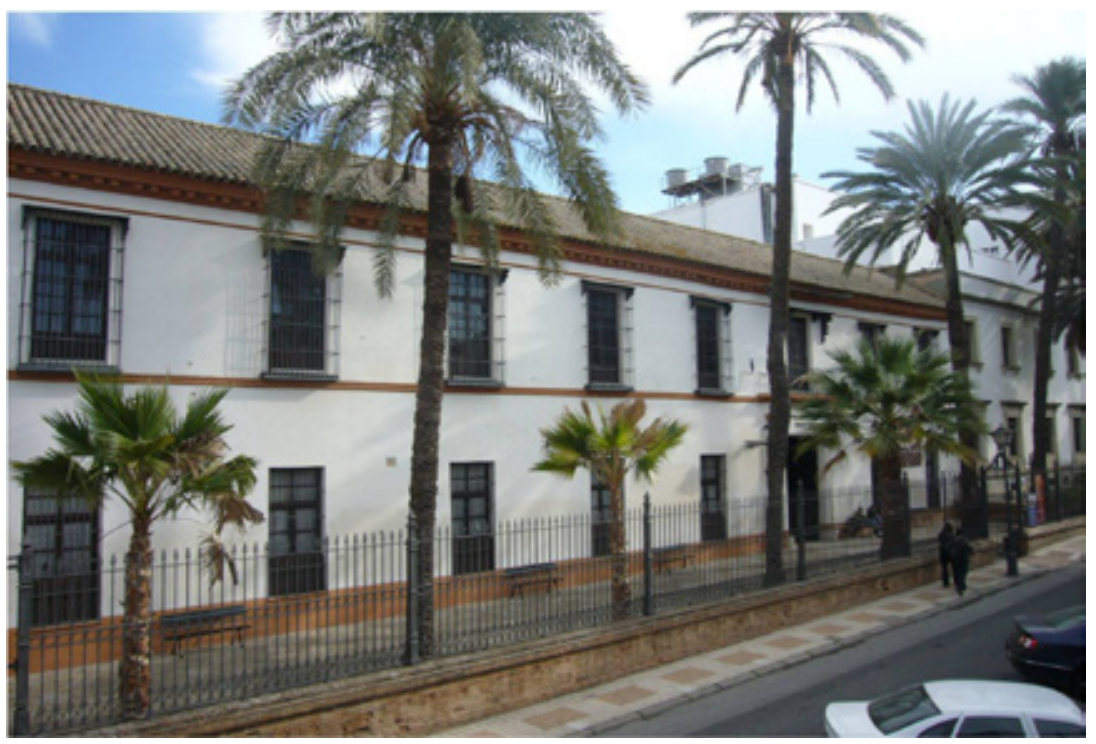

Figura 5. Fachada del hospital.

LABORATORIO DE ARTE 29 (2017), pp. 329-358, ISSN 1130-5762 e-ISSN 2253-8305 - DOI http://dx.doi.org/10.12795/LA.2017.i29.18 


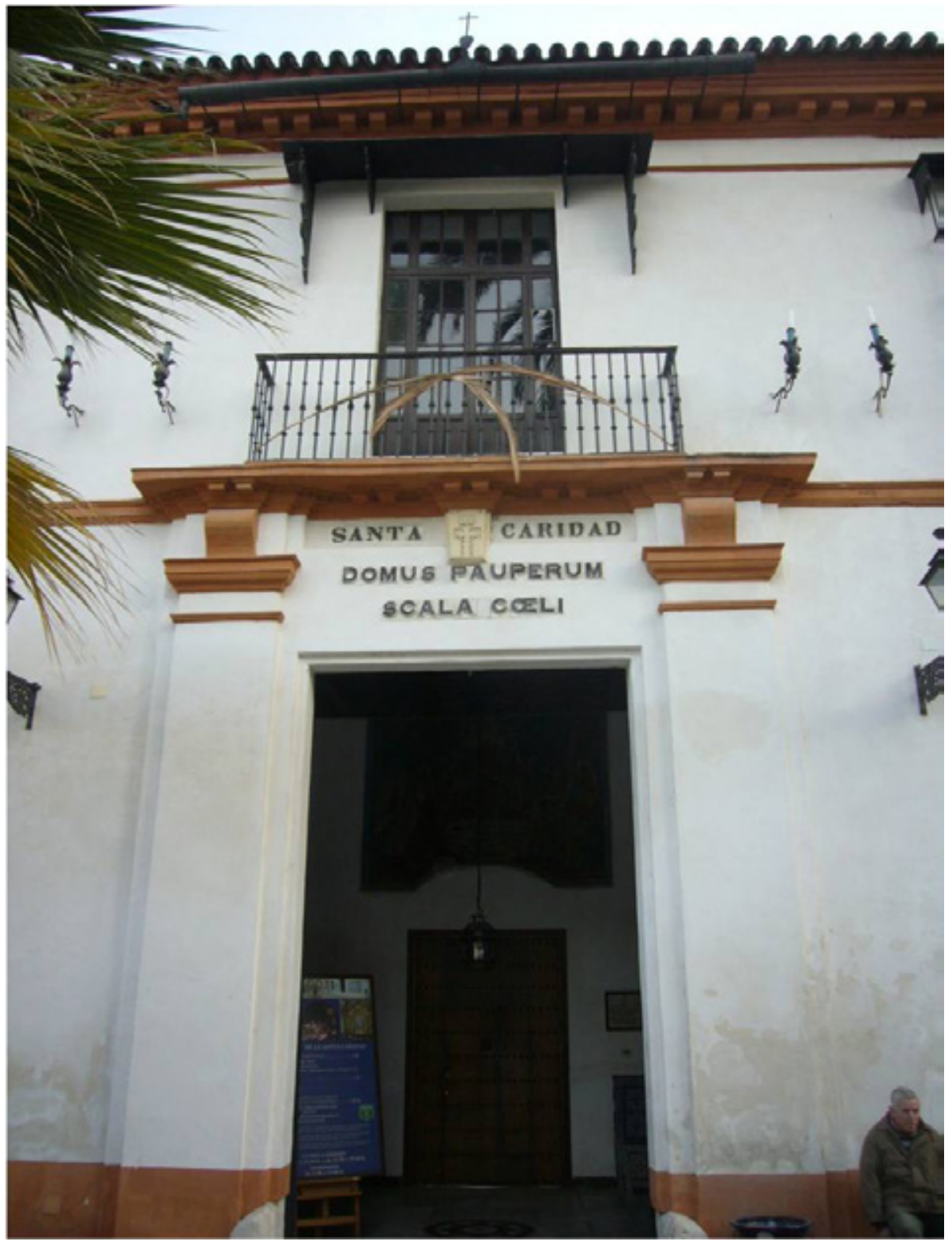

Figura 6. Portada del hospital. 


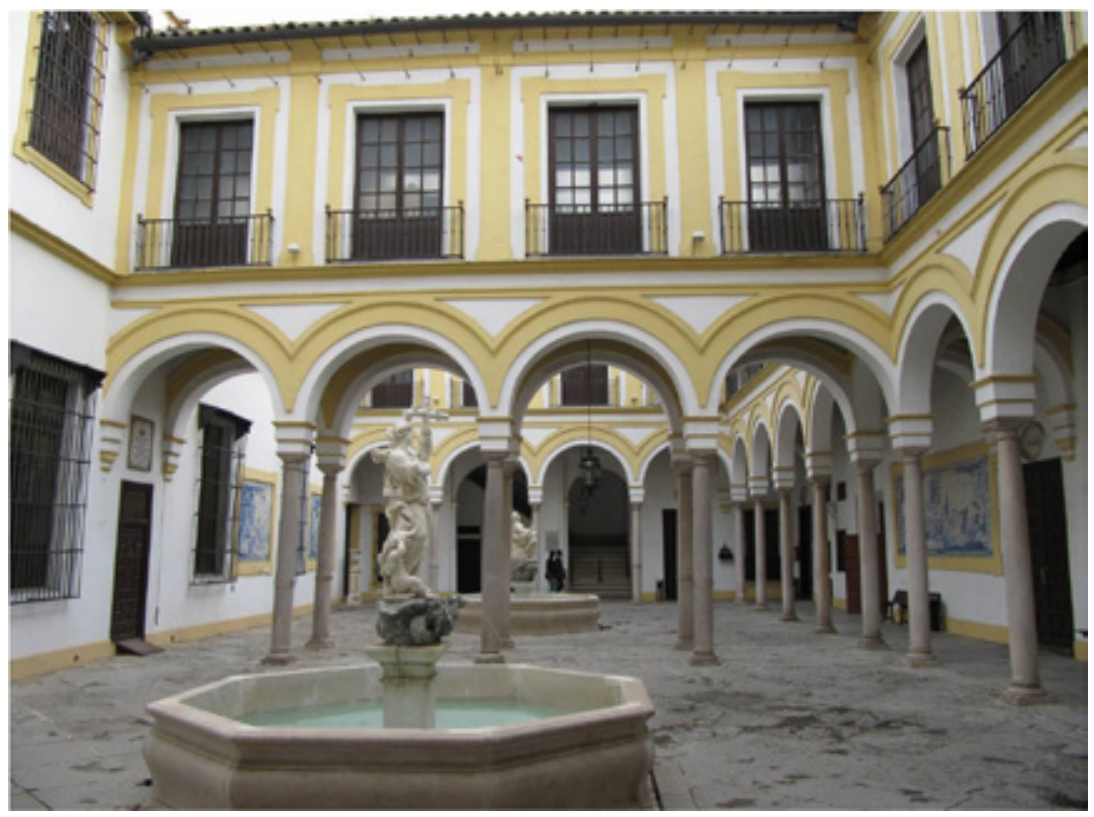

Figura 7. Patio principal.

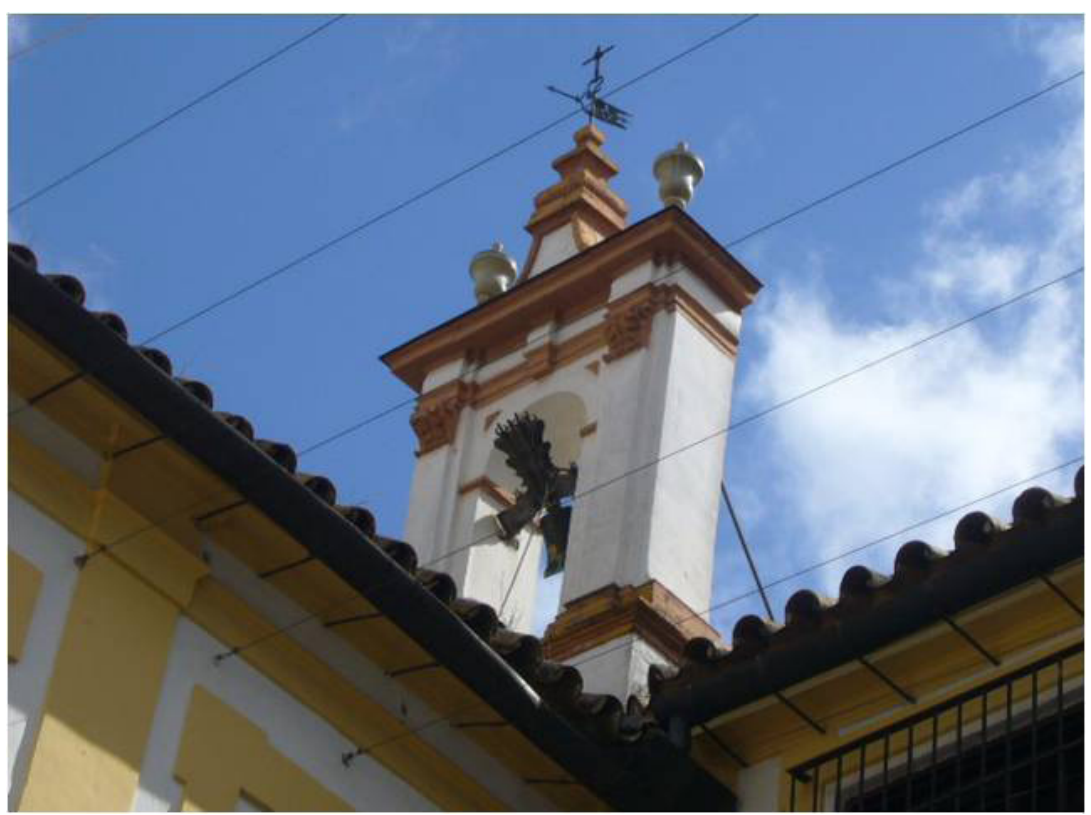

Figura 8. Espadaña del patio, 1682.

LABORATORIO DE ARTE 29 (2017), pp. 329-358, ISSN 1130-5762 e-ISSN 2253-8305 - DOI http://dx.doi.org/10.12795/LA.2017.i29.18 

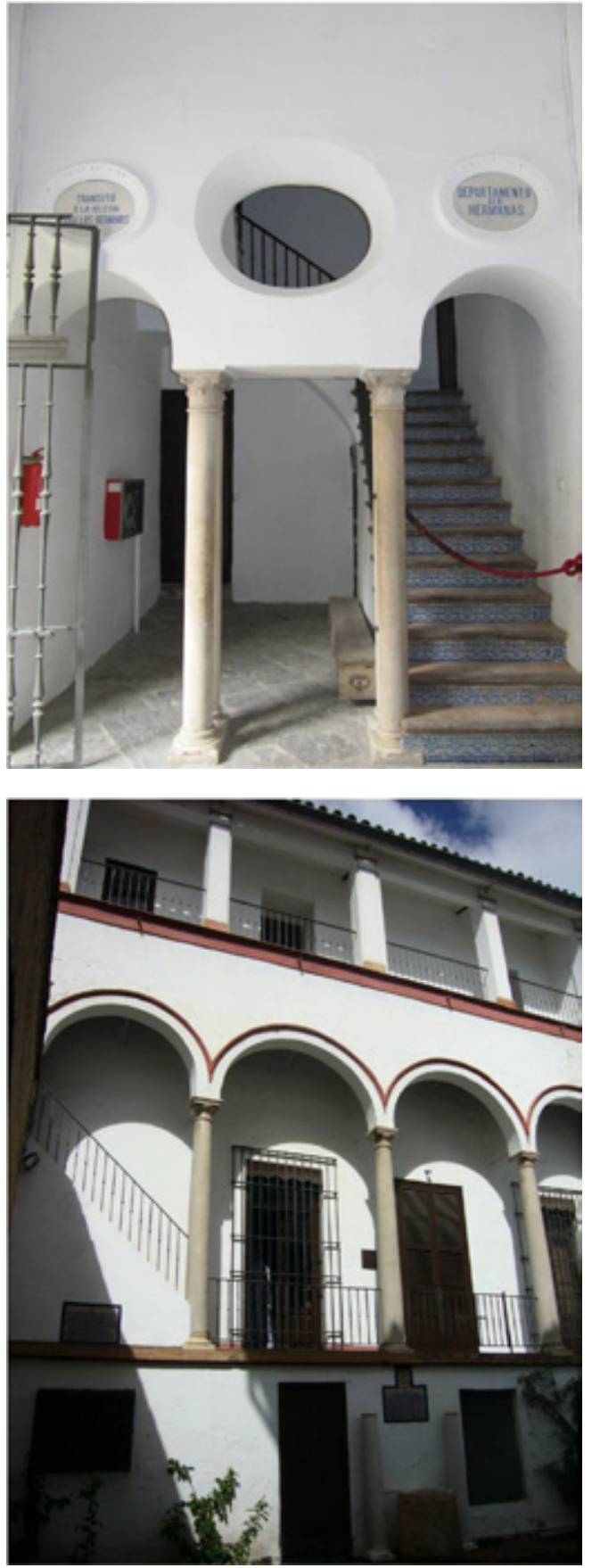

Figura 9. Escalera de tránsito a la iglesia y departamento de hermanas.

Figura 10. Aposentos en los que vivió Miguel Mañara durante sus últimos años. 